\title{
La agencia compartida de plantas y humanos en la elaboración del mosaico paisajístico de Río de Janeiro del ochocientos. Una propuesta metodológica*
}

\section{Resumen}

Las iconografías sobre la ciudad de Río de Janeiro del siglo XIX, Brasil, así como la identidad brasileña, fueron creadas principalmente por una diversidad que incluía factores nativos y exóticos de la flora, fauna, sociedades y culturas, además de la mirada extranjera. El problema de ser utilizadas las imágenes solamente como una ilustración o percibirlas de forma fragmentada, resulta en la limitación de su análisis. Al ser usada la iconografía como fuente primaria en los estudios de las humanidades ambientales se hace posible una lectura más integradora de los paisajes pretéritos, destacando conjuntamente los aspectos botánicos, geográficos, culturales, entre otros. De ese modo, proponemos un análisis interdisciplinario sobre las imágenes, en el cual buscamos evidenciar la agencia compartida de la flora y del trabajo de negros/as esclavizados en conjunción con la mirada extranjera. Desde ese enfoque, mostramos que las iconografías son capaces de revelar la interactuación entre agentes humanos y no humanos en los procesos de transformación de los ambientes registrados.

\section{Palabras clave}

Tesauro: historia latinoamericana, historia del Arte, metodología, paisaje, medio ambiente, Brasil.

Referencia bibliográfica para citar este artículo: Capilé, Bruno y otros. "La agencia compartida de plantas y humanos en la elaboración del mosaico paisajístico de Río de Janeiro del ochocientos. Una propuesta metodológica". Anuario de Historia Regional y de las Fronteras 26.2 (2021): 49-80.

Fecha de recepción: 5/11/2020

Fecha de aceptación: 14/02/2021

Bruno Capilé: Doctor en Historia por la Universidade Federal do Rio de Janeiro. Investigador asociado del Programa Nacional de Apoio à Pesquisa da Fundação Biblioteca Nacional (PNAP-2020/FBN), e do Laboratório de História e Natureza (LabHeN/UFRJ). Correo electrónico: brcapile@gmail.com. Código ORCID: 0000-0001-8860-7584.

Ana Marcela França: Doctora en Historia. Investigadora del Centro de Estudios de la Argentina Rural de la Universidad Nacional de Quilmes, Laboratorio de Hitória e Naturaleza. Correo electrónico: anamarcelaf@ hotmail.com. Código ORCID: 0000-0002-8731-5296.

Gabriel Paes da Silva Sales: Mestre em Geografia. Pesquisador participante do Laboratorio de Biogeografia e Ecologia Histórica (LaBEH), da PUC-Rio, e, do Laboratório História e Naturaleza (LabHeN), da UFRJ. Correo electrónico: paes.sales.gabriel@gmail.com. Código ORCID: 0000-0002-6489-917X.

\footnotetext{
${ }^{*}$ El artículo es resultado del interés de los autores por converger sus investigaciones y de varios encuentros virtuales para organizar ideas y escribir extractos. Aunque cada autor tiene financiación personal para su investigación, no hubo financiación directa para el artículo. El financiamiento de Bruno Capilé provino del Programa Nacional de Apoio a Pesquisa da Biblioteca Nacional, Brasil, (PNAP 2020 / FBN), el de Ana Marcela França fue el Consejo Nacional de Investigaciones Científicas y Técnicas, Argentina, (CONICET) y el de Gabriel Paes da Silva Sales fue su beca de doctorado de la Coordenação de Aperfeiçoamento de Pessoal de Nível Superior, Brasil, (CAPES).
} 


\title{
The Shared Agency of Plants and Humans in the Elaboration of the Landscape Mosaic of Nineteenth- Century Rio de Janeiro: a Methodological Proposal
}

\begin{abstract}
The iconographies about Nineteenth-century Rio de Janeiro, RJ, Brazil, and the Brazilian identity itself were created mainly by a diversity that included native and exotic factors of flora, fauna, societies, and cultures as encompassing the foreign look itself. Using the images only as an illustration, or perceiving them in a fragmented way, results in the limitation of their analysis. By using iconography as a primary source for studies of environmental humanities, it is possible to make a more integrated reading of past landscapes, jointly highlighting botanical, geographic, cultural aspects, among others. Thus, it is proposed an interdisciplinary analysis of the images, in which it is sought to highlight the shared agency of flora and the work of the enslaved black people in conjunction with the foreign gaze. Through this approach, it is demonstrated that these iconographies can reveal the interaction between human and non-human agents in the transformation processes of the environments portrayed.
\end{abstract}

Keywords

Tesauro: Latin American History, Art History, Methodology, Landscape, Environment, Brazil.

\section{A agência compartilhada de plantas e humanos na elaboração do mosaico de paisagens do Rio de Janeiro oitocentista: uma proposta metodológica}

\section{Resumo}

As iconografias sobre o Rio de Janeiro oitocentista, RJ, Brasil, assim como a própria identidade brasileira, foram criadas, principalmente, por uma diversidade que incluía fatores nativos e exóticos da flora, da fauna, das sociedades e das culturas, assim como englobava o próprio olhar estrangeiro. O problema de se empregar as imagens apenas como ilustração, ou percebê-las de forma fragmentada, resulta na limitação de sua análise. Ao utilizar a iconografia como fonte primária para estudos de humanidades ambientais é possível fazer uma leitura mais integrada das paisagens pretéritas, destacando conjuntamente aspectos botânicos, geográficos, culturais, entre outros. Destarte, propomos uma análise interdisciplinar sobre as imagens, nas quais buscamos evidenciar a agência compartilhada da flora e do trabalho dos negros/as escravizados/as em conjunto com o olhar estrangeiro. Através dessa abordagem, demonstramos que estas iconografias podem revelar a interação entre agentes humanos e não humanos nos processos de transformação dos ambientes retratados.

Palavras-chave

Tesauro: história latino-americana, história da arte, metodologia, paisagem, meio ambiente, Brasil. 
Em meados de julho, cheguei ao porto do Rio de Janeiro, onde se abriu todo um novo mundo para mim. Desenhava dia e noite". - Thomas Ender, c. 1817 . $^{1}$

A natureza tropical das Américas impressionou os europeus que por aqui chegaram pela primeira vez no início do século XIX. A combinação do mar, das florestas, das rochas e das montanhas formava um cenário novo a ser explorado pelos artistas-viajantes. A grande quantidade e qualidade dos desenhos, pinturas e gravuras sobre a natureza tropical brasileira foi difundida e comercializada em livros e revistas que circularam pelo mundo ocidental no início do século XIX. Ademais, foi na cidade do Rio de Janeiro oitocentista que a maioria destes naturalistas viajantes iniciou seus primeiros traços sobre as paisagens brasileiras. Diversos fatores incentivaram a chegada de pintores/as europeus ao Brasil, como: (1) a facilidade de acesso pelo oceano via correntes marítimas em sua costa leste; (2) a difusão de notícias favoráveis de relativa estabilidade política nas duas primeiras décadas do XIX (especialmente em comparação com as antigas colônias espanholas); (3) a oportunidade de praticar o gênero da paisagem e de conseguir uma nova clientela no Brasil e até mesmo na Europa e; por fim, (4) a beleza cênica das paisagens, tão diferentes das paisagens europeias. ${ }^{2}$

Além da visão de mundo eurocêntrica, observamos que as paisagens cariocas retratadas como uma concepção de Brasil eram, na realidade, uma construção estética local de ambientes construídos coletivamente por mãos humanas (majoritariamente por negros e negras escravizados/as) e pela agência de espécies vegetais. Sendo assim, nossa proposta parte da perspectiva de uma análise sobre como a ciência e a arte de tradição europeia (travestida de universal) representaram as paisagens da flora carioca como uma natureza brasileira, junto à agência de negros/as escravizados/as e espécies vegetais, no processo de construção material e estética destas paisagens.

Deste modo, mostraremos que a construção das paisagens cariocas foi um processo resultante de três fatores inter-relacionados. O que facilmente emerge em nossas explicações é a própria elaboração estética das diferentes paisagens pelos artistas-viajantes europeus, dotados, como dito anteriormente, de um eurocentrismo marcado pela prática, pela formação e pela sociabilidade a qual experimentavam, no contexto das expedições científicas. Em segundo lugar, um pouco menos evidente, existe a participação histórica do trabalho humano na transformação material das paisagens. No caso do Rio de Janeiro, este trabalho era realizado majoritariamente por negros e negras, livres ou não, apresentando, assim, alguns padrões estéticos que os pintores/as europeus dificilmente observariam na ausência deste trabalho humano. Por fim, verificamos que algumas espécies de plantas, frequentemente retratadas, atuavam com seus hábitos, diversidade e presença na elaboração das paisagens. Percebemos que certas espécies da flora são recorrentes em cenários específicos, em que o artista desejava representar em uma mesma paisagem tanto a vegetação da região quanto à presença humana local.

\footnotetext{
${ }^{1}$ Júlio Bandeira y Robert Wagner, Viagem nas Aquarelas de Thomas Ender - 1817-1818 (Petrópolis: ed. Kapa, 2000) 661.

${ }^{2}$ Lilia Moritz Schwarcz, "Paisagem e Identidade: a construção de um modelo de nacionalidade herdado do período joanino", Acervo, 22, 1, (2009): 19-52.
} 
À vista disso, por exemplo, percebemos que a bananeira (Musa spp.), ${ }^{3}$ herbácea exótica de grande porte e de rápido crescimento, muito utilizada para alimentação, se tornou elemento gráfico recorrente em paisagens suburbanas da cidade. Por sua vez, as embaúbas (Cecropia spp.), nativas das Américas, que possuem como característica a madeira leve, o rápido crescimento e são classificadas como pioneiras, ocorrendo nas clareiras e/ou nas bordas das florestas, figuram, geralmente, em paisagens florestais.

Delimitamos nosso recorte temporal para o início do século XIX (18171835) devido a algumas particularidades que reforçam como a visão de natureza carioca, construída pelos artista-viajantes, foi parte de diversos elementos resultantes da ocupação humana e das relações transatlânticas. Primeiramente, o ambiente local da cidade do Rio de Janeiro e seus arredores já se encontravam transformados. Isso se deu tanto pela alteração do mosaico de ambientes (urbano, suburbano, rural e florestal), quanto pelo trabalho de negros e negras escravizados/as, trazidos à força, num esquema perverso de comércio pelo Atlântico, como também pela agência não-humana de espécies nativas e, principalmente, exóticas de interesse comercial ou utilitário, cultivadas nas Américas e representadas nas imagens. Por exemplo: gramíneas africanas (capim-colonião (Megathyrsus maximus (Jacq.) B.K.Simon \& S.W.L.Jacobs) e capim-gordura (Melinis minutiflora P.Beauv.)), café (Coffea arabica L.), bananeira (Musa spp.), jaqueira (Artocarpus heterophyllus Lam.), mamoeiro (Carica papaya L.), dentre outras.

Em segundo lugar, o momento histórico do mundo ocidental, agitado pelas transformações revolucionárias, forneceu uma transição política de continuidade da coroa portuguesa nas colônias luso-brasileiras. Mas, além disso, ocorreu a renovação da presença das ciências naturais no Estado, especialmente na figura do ilustrado rei português, Dom João VI, e seu filho Dom Pedro I. Portanto, ao fugir para o Brasil com sua corte em 1808, Dom João VI se viu na missão de constituir a recente coroa tropical de instituições que o auxiliariam na organização estrutural do Império português, especialmente o Jardim Botânico, a Academia Imperial de Belas Artes, o Museu Real, a Imprensa Régia e a Escola Militar. ${ }^{4}$

Com a abertura dos portos brasileiros às "nações amigas" em $1808,{ }^{5}$ por parte da coroa portuguesa, o Brasil começou a ser esboçado por naturalistas e artistas-viajantes

\footnotetext{
${ }^{3}$ Optou-se por utilizar a nomenclatura botânica atualizada. Assim, todos os nomes científicos foram verificados no sítio eletrônico do Projeto Flora do Brasil 2020 em construção (Flora do Brasil $2020 \mathrm{em}$ construção). Jardim Botânico do Rio de Janeiro. Disponível em: http://floradobrasil.jbrj.gov.br/. (07 oct. 2020). Segundo Langdon, a banana, antes Musa paradisiaca L., agora pode ser M. balbisiana Colla ou $M$. acuminata Colla, muito provavelmente o último nome. Antes chamada pelos portugueses popularmente como figo-de-Adão, a planta veio ao Brasil da costa ocidental da África, junto com o seu nome: banana. Langdon, Robert. "The banana as a key to early American and Polynesian history", The Journal of Pacific History, 28, 1, (1993): 15-35.

${ }^{4}$ Dantes, Maria Amélia M, Espaços da Ciência no Brasil: 1800-1930 (Rio de Janeiro: Editora Fiocruz, 2001).

${ }^{5}$ Antes desse decreto régio, a coroa portuguesa proibia a entrada de pessoas de outros países europeus que não fossem autorizadas. Embora tenham ocorrido eventos que resultaram na presença de franceses no Rio de Janeiro no século XVI, e de holandeses na região do estado Pernambuco, no século XVII.
} 
que buscavam compreender e representar o território luso-brasileiro, praticamente desconhecido do restante da Europa. ${ }^{6}$ Neste contexto, houve a contratação e apoio à vinda de expedições científicas e missões artísticas para compreender a natureza brasileira do ponto de vista de um Estado recente. Os artistas-viajantes que retrataram a tropicalidade carioca junto a expedições científicas fortaleceram as tendências da arte romântica e dos traços botânicos dos naturalistas, em uma mistura humboldtiana de arte e ciência. Porém, as paisagens cariocas foram as que mais se destacaram na representação da natureza brasileira, confundindo apreciadores desavisados sobre a diversidade do território.

No presente artigo, um exemplo foi nossa atenção muitas vezes voltada para as espécies vegetais iconizadas nas imagens da tropicalidade carioca, que mesclavam elementos urbanos e suburbanos junto à ruralidade e às florestas do entorno do Rio de Janeiro. Alinhado ao campo da história ambiental, compreendemos essa complexidade socioecológica como fruto da agência compartilhada da transformação da paisagem pelo trabalho das mãos negras, pelas especificidades dos inúmeros indivíduos vegetais e, particularmente, pela construção estética dos artistas-viajantes europeus. Dessa maneira, a proposta deste artigo é oferecer uma análise interdisciplinar sobre imagens de paisagens do Rio de Janeiro oitocentista, nas quais buscamos evidenciar a agência compartilhada da flora e do trabalho dos negros/as escravizados/as em conjunto à composição artística de pintores/as europeus. Portanto, na primeira parte do artigo apresentamos as bases teóricas que sustentam a nossa proposta metodológica, para em seguida fazer as análises das imagens propriamente ditas. Analisamos gravuras e diários de quatro artistas-viajantes: Thomas Ender (1793-1875), Johann M. Rugendas (1802-1858), Maria Graham (1785-1842) e Henry Chamberlain (1796-1844). Com exceção de Rugendas, foram analisadas uma obra de cada artista, totalizando cinco imagens. Todos estiveram no Brasil na primeira metade do século XIX e a escolha deles se deu mais pelas gravuras selecionadas do que por suas biografias.

\section{Múltiplas ferramentas epistemológicas para elaborar narrativas de agências compartilhadas}

Desenvolvemos nossa metodologia interdisciplinar alinhada com a tríade de agentes que, desde o nosso ponto de vista, participaram da construção das paisagens cariocas. Ou seja, plantas, negros/as e pintores/as são analisados como agentes a partir do olhar cruzado da Geografia, da História Ambiental, da História da Arte e da Biologia. Para isso, foi necessário discutir primeiramente alguns conceitos chave que serão utilizados no processo de análise das imagens.

\section{Paisagem}

O conceito de paisagem, em sua complexa polissemia, pode ser interpretado tanto como ambiente biofísico, quanto a sua representação. Atualmente, no que tange os usos deste conceito na história ambiental, é possível verificar uma rica discussão

\footnotetext{
${ }^{6}$ Schwarcz 19-52. Lorelai Kury, "Viajantes-naturalistas no Brasil oitocentista: experiência, relato e imagem”, História, Ciências, Saúde-Manguinhos, VII (suplemento), (2001): 863-80.
} 
da maneira como vem sendo empregado. Corrêa ${ }^{7}$ analisou dezenas de referências de história ambiental que abordaram o conceito de paisagem. Para ela, a diversidade das investigações sobre as paisagens pretéritas tiveram dois pressupostos: o da concretude da realidade material visualizada dos ambientes; e a percepção visual e construção estética deste espaço físico. Por um lado, trata-se de uma categoria de espaço, onde o ambiente possui uma história co-evolutiva entre humanos, plantas, animais e o meio biofísico. Por outro lado, a representação humana, repleta de intencionalidades, possui uma forte relação entre o cenário retratado e a arte, em especial a pintura.

A paisagem se trata de um testemunho humano, em que suas múltiplas escalas espaciais e temporais, associadas às perspectivas plurais dos pontos de observação, criam possibilidades interpretativas que, quando integradas num esforço interdisciplinar, amplificam sua compreensão, tanto como redimensionam sua complexidade e riqueza. ${ }^{8}$ Portanto, tomamos a paisagem como um documento histórico, ${ }^{9}$ considerando tanto os registros científicos realizados pelos/as artistasviajantes, como a carga cultural pertencente aos seus contextos de origem. Neste contexto, é fundamental considerar a influência do naturalista alemão Alexander von Humboldt no processo de conhecimento do universo natural e na construção da paisagem por meio da arte. ${ }^{10}$

Escrito por Humboldt na primeira metade do século XIX, o livro "Quadros da Natureza" inovou os relatos de viagens ao introduzir o discurso estético mesclado ao rigor científico. ${ }^{11}$ Partindo da ideia de natureza, enquanto parte de uma totalidade, as descrições naturalistas seriam limitadas caso se detivessem somente ao rigor da linguagem das ciências naturais. Deste modo, aos olhos do naturalista alemão, juntamente às informações escritas, o universo natural era devidamente representado pelas pinturas, desenhos e gravuras de paisagem. Segundo ele:

Quaisquer que sejam a riqueza e flexibilidade de uma língua, não é todavia empresa sem dificuldades a de descrever, por meio de palavras, o que só a arte do pintor pode representar, não falando na necessidade de se precaver contra a impressão monótona, que é a consequência necessária de uma enumeração bastante prolixa de objetos. ${ }^{12}$

O modelo paisagístico para Humboldt se estruturava na junção de paisagens ideais e descritivas, onde era apresentada "uma visão ao mesmo tempo total e sintética". ${ }^{13}$ A complexidade do universo natural podia ser devidamente organizada

\footnotetext{
${ }^{7}$ Dora Shellard Corrêa, "História ambiental e paisagem", História Ambiental Latinoamericana y Caribeña, 2 , 1 (2012): 47-69; "Paisagens através de outros olhares", Revista de História Regional, 20, 2 (2015): 252-276.

${ }^{8}$ Jean-Marc Besse, Ver a terra: seis ensaios sobre a paisagem e a geografia. (São Paulo, Ed. Perspectiva, 2006).

${ }^{9}$ Donald Worster, "Para fazer história ambiental", Revista Estudos Históricos, 4, 8 (1991): 198-215.

${ }^{10}$ Marcia Regina Capelari Naxara, Cientificismo e sensibilidade romântica (Brasília: Editora UNB, 2004).

${ }^{11}$ Ricotta, Lúcia. "A paisagem em Alexander von Humboldt: o modo descritivo dos quadros da natureza". Revista Usp, 46 (2000): 97-114.

${ }^{12}$ Alexander von Humboldt, Quadros da Natureza (São Paulo, Editora Brasileira [1849] 1957) 289.

${ }^{13}$ Cláudia Valadão Mattos, "A pintura de paisagem entre arte e ciência: Goethe, Hackert e Humboldt",
} 
no espaço ilusório da paisagem pictórica, conferindo a esta a credibilidade necessária para fornecer informações de base naturalista. No modelo de paisagem de Humboldt, os aspectos biofísicos de uma dada localidade eram fornecidos juntamente a uma visão estética sobre a mesma, na intenção de ser reproduzido o caráter orgânico da natureza. Ou seja, o rigor da linguagem científica por si só não alcançaria a essência vital do universo natural, formado por sua força, beleza, mistério e dinâmica próprias. Em se tratando de um mundo orgânico a ser explorado pelas ciências, a arte era capaz de apresentar a totalidade que envolvia as distintas dimensões da vida:

As plantas doentias, encerradas nas nossas estufas, não representam senão muito incompletamente a majestade da vegetação tropical; mas, na perfeição da linguagem, na brilhante fantasia do poeta, e na arte imitadora da pintura, há manancial abundante de compensações onde a nossa imaginação pode encontrar as imagens vivas da natureza exótica. ${ }^{14}$

É um modo de observação e apreensão do meio que influenciará a literatura de viagem oitocentista, nas quais as paisagens reproduzidas nas pranchas serão uma via de acesso ao conhecimento da flora, da fauna e das culturas das distintas regiões brasileiras. Seria necessário compreender, assim, que a paisagem pictórica não era simplesmente um espaço ilusório construído pela arte, mas também um conjunto de valiosas informações científicas.

Influenciados por Humboldt, inúmeros viajantes cruzaram o Atlântico para conhecer e registrar a natureza sul-americana ao longo do século XIX. Nessas expedições, além de cientistas naturais e profissionais de diversos ofícios, estavam os artistas e/ou desenhistas de formação não necessariamente artística. Estes faziam o registro visual das espécies da flora e da fauna, assim como os costumes e gentes de cada região percorrida. Em suas paisagens temos inúmeros exemplos de formações vegetais, rochosas ou hídricas, que testemunham ambientes modificados ao longo de sua história ou que se mantiveram conservados. ${ }^{15}$

\section{História da Arte}

$\mathrm{Na}$ virada para o século XIX, uma considerável parcela da produção pictórica europeia se voltou para os sentimentos da natureza traduzidos na iconografia de paisagem. Ao dar abertura às expressões mais subjetivas do artista, o romantismo ofereceu maior liberdade na composição pictórica e na escolha dos temas. $\mathrm{O}$ movimento romântico questionou a visão essencialmente racionalista das sociedades industriais ao dar abertura aos sentimentos individuais nos processos artísticos. ${ }^{16}$

\footnotetext{
Revista Terceira margem, VIII, 10, (2004): 152

${ }^{14}$ Humboldt 299.

${ }^{15}$ Ana Marcela França, “As imagens de paisagem como testemunhos de transformação e memória de áreas de conservação”, Boletín De Estudios Geográficos, 112 (2019): 9-45.

${ }^{16}$ Emily Brady, Aesthetics of the natural environment (Edinburgh University Press, 2003).
} 
Assim como a estética do sublime, a noção do pitoresco foi significativa dentro do movimento romântico, ao ter estimulado a apreciação do ambiente natural por suas características orgânicas e por ser associado a um ambiente prazeroso, agradável, com uma natureza de aparência livre e quase edênica. ${ }^{17}$ Admitimos que a estética do pitoresco, difundida no século XIX em inúmeras pinturas, pode ter contribuído com a criação de condições para que as florestas da costa brasileira pudessem ser apreciadas no contexto dos artistas-viajantes. Provavelmente, por elas responderem, de alguma maneira, às tais premissas estéticas através da combinação da variedade de suas cores, de suas formas confusas - porém intrigantes - e por sua diversidade tão exótica aos olhos de muitos europeus. ${ }^{18} \mathrm{O}$ exotismo era um elemento que também compunha o pitoresco, como, por exemplo, a presença da arquitetura oriental nos jardins e nas pinturas europeias. ${ }^{19}$

No romantismo, o gênero paisagem foi de fato valorizado por meio da pintura de diversos artistas europeus, como Caspar D. Friedrich e William Turner. ${ }^{20}$ O sentimento de totalidade entre ser humano e o universo natural foi expresso através das pinturas de paisagem, as quais davam destaque à grandiosidade da natureza ou configuravam um sentimento acolhedor de comunhão com esta. ${ }^{21} \mathrm{O}$ desejo de conhecer o universo natural não se limitou ao ateliê e às galerias de arte, mas impulsionou alguns artistas a desbravarem as paisagens dos "novos" continentes.

Dentre as diversas gravuras que foram analisadas, elegemos cinco para exemplificar nossa hipótese central. Estas foram eleitas por demonstrar com clareza a presença de certas espécies vegetais relacionadas às distintas dimensões da cidade carioca (urbana, suburbana, rural e florestal), ao trabalho escravo e ao padrão imagético europeu aplicado aos trópicos, para ser divulgado pelo Velho Mundo. Os autores dos desenhos originais influenciaram na nossa escolha, devido aos detalhes apresentados e ao modo como foi construída a paisagem representativa do Brasil. É necessário esclarecer que a maioria das representações paisagísticas eram elaboradas quando seus autores retornavam à Europa. Em geral, os artistas-viajantes partiam de um esboço realizado in situ para posteriormente conceberem o trabalho final, agregando ou subtraindo elementos na composição da paisagem que viria a ser a definitiva. ${ }^{22}$ Esta prática era comum na época e de maneira alguma desvalorizava o valor informativo das imagens. Ao contrário, garantia que a paisagem pudesse representar os variados aspectos do lugar registrado, desde os botânicos aos costumes locais. Por isso, nossa intenção não é encontrar uma paisagem "verdadeira" do Rio de Janeiro oitocentista,

\footnotetext{
${ }^{17}$ Giulio Carlo Argan, Arte Moderna (São Paulo: Companhia das Letras, 2002).

${ }^{18}$ Ana Marcela França, “As “pitorescas” florestas da Mata Atlântica nas paisagens dos viajantes”, Revista Labirinto, XVIII, 29 (2018).

${ }^{19}$ Brady 112.

${ }^{20}$ Norbert Wolf, Romanticism (London: Taschen, 2007); E. H Gombrich, História da arte (Rio de Janeiro, LTD, 1999).

${ }^{21}$ Wolf 38.

${ }^{22}$ Sobre a elaboração das imagens verificar: https://www.brasilianaiconografica.art.br/artigos/20195/eplagio-a-repeticao-de-personagens-e-cenas-nos-registros-dos-artistas-viajantes
} 
mas justamente o que nos interessa é discutir como que essa amálgama de elementos variados conformavam a percepção de natureza na época sob o olhar europeu - e que foi posteriormente adotado pela cultura e intelectualidade brasileira, persistindo em certos aspectos até os dias de hoje. Para Humboldt, a seguinte metodologia era sugerida:

Os esboços realizados diante das cenas naturais só podem levar a reproduzir o caráter de regiões longínquas do mundo após o retorno, em paisagens acabadas. Eles o farão de forma tanto mais perfeita se o artista entusiasmado tiver desenhado ou pintado ao ar livre, diante da natureza, uma grande quantidade de estudos isolados de copas de árvores, de galhos frondosos carregados de flores e frutos, de troncos caídos, cobertos de parasitas ou orquídeas, de rochedos, trechos das margens dos rios e partes do solo da floresta. ${ }^{23}$

As gravuras que compõem os diários de viagem foram elaboradas por gravadores, baseando-se no desenho original do autor. $\mathrm{O}$ gravador era um outro profissional que fazia parte do processo de produção das imagens a serem divulgadas nos livros. Eles possuíam certa autonomia em agregar ou retirar elementos, no entanto respeitavam os originais o quanto possível. Essas imagens eram reutilizadas em distintas publicações de viagens, geralmente dando créditos ao autor e ao gravador, de maneira que foram bastante divulgadas pela Europa. A litogravura possibilitava a combinação de vários elementos soltos a serem postos em uma mesma paisagem. Também podiam ser feitas em cores, o que deve ser considerado no que se refere à representação da diversidade vegetal carioca. Esse método de reprodução tornou possível aumentar o número de publicações de diários de viagens, assim como possibilitou a impressão de imagens coloridas juntamente aos textos. A litogravura contribuiu fortemente para a popularização de uma ciência que não se restringia somente a um círculo específico. ${ }^{24}$ Certamente, o aumento das publicações intensificou a divulgação das "excêntricas" terras tropicais.

A natureza brasileira foi objeto de estudos para botânicos, naturalistas, artistas, entre outros profissionais que buscavam registrá-la e divulgá-la entre homens e mulheres letrados do velho continente. Stepan, ${ }^{25}$ em Picturing Tropical Nature, comenta que as imagens tornavam a narrativa interessante ao mesmo tempo em que davam conta da história natural. Segundo a autora, a natureza tropical foi uma construção tanto imaginativa quanto empírica, em que por muitas vezes, o viajante tinha que corresponder às expectativas de seus leitores através da produção de uma narrativa acurada, realista e interessante. Diante disso, os autores acabavam por ter que se adaptar às "convenções visuais de como o mundo natural deveria aparentar". ${ }^{26}$ Um exemplo, foi inserir a floresta carioca no espaço tridimensional artificialmente construído no papel ou tela, como bem apontou Siqueira. ${ }^{27}$ Uma convenção de tradição

\footnotetext{
${ }^{23}$ Humboldt apud Mattos 161.

${ }^{24}$ Mary Louise Pratt, "Humboldt e a reinvenção da América”, Estudos Históricos, 4, 8 (1992): 151-165.

${ }^{25}$ Nancy Stepan, Picturing tropical nature (London: Reaktion Books Ltd, 2001).

${ }^{26}$ Nancy 45.

${ }^{27}$ Vera Beatriz Siqueira, "Contrastes naturais: imagens da flora brasileira”, Martins, Ana Cecília. (Org.). Flora Brasileira: História, Arte \& Ciência. (Rio de Janeiro: Casa da Palavra, 2009) 128-165.
} 
europeia baseada, entre outras coisas, na combinação dos cheios e vazios em uma composição pictórica, a fim de se obter a tridimensionalidade dos objetos e do espaço receptivo deles. Esse tipo de espacialidade se estrutura no uso da perspectiva, como por exemplo, uma visão distanciada com um ponto de fuga no horizonte. Como fazer isso dentro das densas florestas tropicais brasileiras, onde o emaranhado das diversas formas de vida das espécies vegetais competem por luz e espaço? Rugendas destacou:

As florestas nativas constituem a parte mais interessante das paisagens do Brasil; mas também a menos suscetível de descrição. Em vão procuraria o artista um posto de observação nessas florestas em que o olhar não penetra além de poucos passos; as leis de sua arte não lhe permitem exprimir com inteira fidelidade as variedades inumeráveis das formas e das cores da vegetação em que ele se vê envolvido. ${ }^{28}$

Esse mundo novo forçou certa adaptação da técnica artística que os artistas-viajantes traziam do exterior. A linguagem poética combinada à científica era um modo de visualização e escrita que dava conta tanto do conhecimento como da leitura prazerosa do conteúdo: "cabia aos artistas-viajantes não apenas registrar determinada realidade cultural e natural, mas também convencer o público europeu da plausibilidade e veracidade de seu discurso". ${ }^{29}$

Ao combinar elementos característicos em uma mesma gravura, e pela repetição desses elementos, foi possível construir "realidades" e identidades. "A cada nova imagem, reafirma-se a imagem original de uma cidade-natureza [Rio de Janeiro], dominada pela cor local do país". ${ }^{30}$ Desta maneira, a pintura, o desenho ou a gravura das paisagens no contexto das viagens oitocentistas aparece, então, adequada à ilustração de tipo abrangente do mundo tropical. As pranchas que acompanhavam os textos na publicação eram, assim, tão informativas quanto o conteúdo escrito.

\section{História Ambiental e agência vegetal}

Em suas múltiplas dimensões, o campo da história ambiental concebe que o ambiente tem uma importância histórica nas sociedades humanas. As obras destacadas nos fornecem um reforço analítico que permite compreender como se deram as relações entre os agentes humanos e os não-humanos na transformação dos distintos ambientes cariocas. Embora reconheçamos o protagonismo dos animais na história humana e na transformação do ambiente carioca, nos atentamos mais para os vegetais, atores extensamente representados nas pinturas analisadas. Para tanto, veremos nesta seção como concebemos a agência vegetal na construção material e estética da paisagem oitocentista.

$\mathrm{Na}$ historiografia tradicional, quando a flora e a fauna aparecem, elas são inseridas numa concepção em que é instrumentalizada para os interesses humanos.

\footnotetext{
${ }^{28}$ Johann. M Rugendas, Viagem Pitoresca através do Brasil. (São Paulo: Círculo do Livro S. A., sin fecha) 14.

${ }^{29}$ Rugendas 525 .

${ }^{30}$ Rugendas 525.
} 
Esse silenciamento de agentes não-humanos impede de os conceber como força transformadora do passado, e nesse vácuo político, a natureza é restringida a ser um mero pano de fundo. ${ }^{31}$ Num sistema de dominação, como o colonial, a narrativa histórica privilegia um grupo hegemônico como o único protagonista histórico, excluindo e negligenciando a agência de grupos humanos periféricos e outras espécies. ${ }^{32}$ Buscamos com nossa metodologia deslocar a subalternidade das paisagens tropicais brasileiras do pensamento hegemônico global e das elites dominantes da região. Admitimos que só através de uma diversidade epistêmica conseguiremos reescrever as narrativas eurocêntricas de dominação da modernidade revalorizando atores apagados e suas histórias de resistência. ${ }^{33}$

Para interpretarmos a agência das plantas, abordaremos como algumas espécies vegetais se destacaram nas imagens. Não em um sentido de inversão da narrativa que apague alguma agência, mas na proposta de Cronon em que "a natureza é coautora de nossas histórias". ${ }^{34}$ Portanto, fazemos eco a Steinberg ${ }^{35}$ que propôs que a história ambiental seja um modo de analisar como o mundo natural restringiu e moldou o passado, como a humanidade afetou os ambientes naturais, e como essas mudanças afetaram a maneira a qual nós humanos construímos nossa história.

Tradicionalmente, a noção de agência se restringe a uma tomada de decisões e ações de forma consciente e deliberada. A crítica dos estudos de agência de plantas e animais (human animal studies e human plant studies) reincide em não concebermos apenas a consciência racional de um cérebro na ação transformadora do passado, e sim toda uma pluralidade de ações que realmente moldaram e modificaram o ambiente. Isso faz mais sentido se interpretarmos a agência de um ponto de vista relacional e ecológico, onde não buscamos uma entidade única na ação histórica, e sim a comunhão de diversos elementos que constituem a paisagem. ${ }^{36}$ Mesmo sendo seres de baixa mobilidade, as plantas exercem ação e estão numa complexa rede de ecologias, lugares, práticas, ideologias e paisagens. Para um aprofundamento nos estudos sobre a interface humanos-plantas seriam necessários três aspectos: (1) a interconectividade radical entre humanos e não-humanos, (2) a necessidade de considerar a agência das plantas e (3) o desafio às metodologias ortodoxas convencionais. ${ }^{37}$

\footnotetext{
${ }^{31}$ Ted Steinberg, "Down to Earth: Nature, Agency, and Power in History", The American Historical Review, 107, 3 (2002): 798-820.

32 Val Plumwood, Environmental Culture: The Ecological Crisis of Reason. Londres: Routledge, 2002.

33 Hector Alimonda, "La colonialidad de la naturaleza: una aproximación a la ecología política latinoamericana", en Alimonda, Hector (ed). La naturaleza colonizada: ecologia política y minería en América Latina (Buenos Aires: CLACSO, 2011): 21-58.

${ }^{34}$ William Cronon, "Un lugar para relatos: naturaleza, historia y narrativa" Germán Palacio y Astrid Ulloa, (eds.) Repensando la naturaleza. Encuentros y desencuentros disciplinarios en torno a lo ambiental. (Bogotá: Universidad Nacional de Colombia/ICANH. 2002) 61.

${ }^{35}$ Steinberg 112.

${ }^{36}$ Russell Hitchings; Verity Jones, "Living with plants and the exploration of botanical encounter in human geography research", Ethics Place Environment, 7 (2004): 3-18.

${ }^{37}$ Diana Gibson; William Ellis, "Human and plant interfaces: relationality, knowledge and practices", Anthropology Southern Africa, 41 (2018): 75-79.
} 
Em relação às imagens, as plantas têm sido representadas por diferentes motivos ao longo da história, desde religiosos até puramente estéticos. Desta maneira, interpretamos a agência delas tanto na elaboração de crenças, práticas e tradições, quanto na adaptação e transformação das paisagens socioecológicas das quais fazem parte. Ou seja, como seres protagonistas de nossa história coletiva, as plantas são parceiras ativas na produção de conhecimento e de práticas culturais, assim como a pintura. ${ }^{38} \mathrm{O}$ que está em questão é que há uma relação humano-planta, onde os sentidos e os sentimentos vivenciados pelo artista são influenciados pela sua relação com as plantas e suas expressões biológicas. Portanto, a história de vida e as demandas sociais e políticas dos artistas-viajantes interagiam ativamente junto às experiências que estes tinham com as plantas, em caminhadas, expedições ou apreciações. ${ }^{39}$

\section{História Ambiental e trabalho}

Muito do que consideramos como "paisagem natural" é o resultado da agência e do trabalho humano. ${ }^{40}$ Utilizaremos o termo ambiente neste artigo para delinear um determinado espaço biofísico e suas relações socioecológicas, especialmente como este foi representado iconograficamente. Williams ${ }^{41}$ explicita a relação entre trabalho e ambiente quando diz que "a ideia de natureza contém, embora geralmente despercebida, uma quantia extraordinária de história humana (...). Uma história profundamente marcada pelo trabalho". Nessa perspectiva, fica clara a historicidade da natureza, em que a sua definição (daquilo que chamamos de natural) é intimamente associada ao uso e a transformação do meio, "um produto do planejamento e do trabalho humano e, ao ser admirado como natural, importa muito se suprimimos dele o trabalho ou se o reconhecemos" ${ }^{\prime 2}$. Portanto, é somente através das forças da natureza que o trabalho humano de transformação dos espaços biofísicos se torna possível ${ }^{43}$. Isso, para a história da colonização das Américas, significa que os diversos ambientes pretéritos à chegada dos europeus já haviam sido transformados por outros agentes humanos e não humanos. Assim como também o são os ambientes cariocas do início do século XIX. Segundo Herrera: "La historicidad de los ambientes está estrechamente vinculada, así, a las formas históricas de organización social del trabajo, y a los propósitos que dicha organización persigue, sea la de valores de uso, sea la de valores de cambio". ${ }^{4}$

Nesse trabalho humano, evidentemente, consideramos os diversos povos ameríndios que já habitavam na região da cidade do Rio de Janeiro, modificando

\footnotetext{
${ }^{38}$ John Charles Ryan, "Passive Flora? Reconsidering Nature's Agency through Human-Plant Studies (HPS)", Societies, 2 (2012): 101-121.

${ }^{39}$ Hitchings e Jones 45.

${ }^{40}$ Rogério Oliveira, "Mata Atlântica, paleoterritórios e história ambiental”, Ambiente \& Sociedade, 10, 2 (2007): 11-23.

${ }^{41}$ Williams Raymond, "Ideias de natureza”, Cultura e materialismo (São Paulo: UNESP, 2011) 89.

${ }^{42}$ Raymond 104

${ }^{43}$ Richard White, The Organic Machine: the remaking of the Columbia River (New York: Hill and Wang, 1995).

${ }^{44}$ Guillermo Castro Herrera, Naturaleza, trabajo y humanidad, 2020.
} 
florestas, mangues, restingas, entre outros ecossistemas. No entanto, por uma relação histórica e proximal com as paisagens retratadas nos quadros oitocentistas, iremos analisar como o trabalho dos/as negros/as escravizado/as transformou as distintas paisagens.

Nas imagens analisadas, a heterogeneidade de ambientes retratados equiparava à diversidade e à intensidade de trabalho braçal. Observamos que havia padrões entre o preparo da terra para o uso de algumas espécies vegetais, o que facilitou, dessa maneira, a elaboração de categorias analíticas destes ambientes retratados que eram montados como mosaicos de paisagens cariocas pelos artistas. Elaboramos as categorias como quatro ambientes contíguos: urbano, suburbano, rural e florestal. No início do século XIX, o centro urbano do Rio de Janeiro se restringia a um espaço diminuto entre os morros São Bento, Castelo, Santo Antônio e Conceição. Em meio ao aglomerado de casas, igrejas, sobrados, lojas e outros edifícios, possuía poucos espaços verdes, com a exceção do Passeio Público, construído no final do XVIII. Ao distanciarmos do centro populoso, o território suburbano é uma fronteira entre cidade e o campo, com aspectos de ambos os ambientes. Neste momento, o subúrbio se iniciava após as franjas do manguezal do Saco de São Diogo a oeste, ou depois das áreas alagadas do Boqueirão ao sul. Uma zona de residência permanente ou temporária de uma elite, assim como, de produção de alimentos. Aqui, a bananeira (Musa spp.), planta asiática, era uma das principais espécies retratadas, talvez pelo seu carisma vegetal. ${ }^{45}$ Foram retratados também mamoeiros (Carica papaya L.) e outras espécies que não foram possíveis de serem identificadas. No entanto, nas chácaras e quintas suburbanas eram encontradas hortaliças e outras árvores frutíferas. Interessante notar que havia capinzais tanto no subúrbio quanto na zona rural, sinal da importância em alimentar equídeos para somar-se ao trabalho humano. ${ }^{46}$

Típico de territórios coloniais, na zona rural destacam-se as espécies de interesse econômico para exportação, como o cafezeiro (Coffea arabica L., por exemplo). De acordo com a fisiologia e as "preferências" deste vegetal, o trabalho humano distribuiu os cafezais nos vales recém desmatados das montanhas cariocas, especialmente nas áreas do maciço da Tijuca. ${ }^{47}$ Por fim, a floresta tem sua alta biodiversidade representada tanto com os indivíduos vegetais, como através de diferentes representações dessa biodiversidade por meio de manchas coloridas, texturas, tamanhos, formas e contrastes diferentes. Nesse sentido, ao mesmo tempo em que os artistas-viajantes estiveram no Rio de Janeiro a esboçar e a desenhar a sua "natureza", o trabalho humano transformava parte da paisagem florestal para o plantio dos cafezais.

\footnotetext{
${ }^{45}$ Carisma é um atributo que causa fascinação, admiração, em quem se relaciona com o carismático. No caso, alguns atributos visuais de certas plantas influenciaram e causaram admiração nos artistas-viajantes. Dessa forma, tais espécies iconizaram paisagens como a bananeira e mamoeiro para as chácaras suburbanas, os cafezeiros e gramíneas exóticas para o território rural etc.

${ }^{46}$ Bruno Capilé, "Os muitos rios do Rio de Janeiro: transformações e interações entre dinâmicas sociais e sistemas fluviais na cidade do Rio de Janeiro (1850-1889)", (Tesis doctoral, Universidade Federal do Rio de Janeiro, 2018).

${ }^{47}$ Maurício de Abreu, Natureza e Sociedade do Rio de Janeiro (Rio de Janeiro: SMCTE/DGDIC/Divisão, 1992).
} 
O olhar da história ambiental para a iconografia que retratou os ambientes oitocentistas foi realizado através de uma diversidade de documentos escritos, mapas históricos, tabelas de reflorestamento, dados meteorológicos etc. Nada obstante, nos apoiaremos igualmente em análises históricas já realizadas, em fontes secundárias. ${ }^{48}$ Ademais, para embasar a história do trabalho negro/a que perpassou os ambientes cariocas, convenientemente categorizados em quatro neste artigo, utilizaremos autores já consagrados no tema. ${ }^{49}$

\section{Análise das imagens ${ }^{50}$}

Sustentados pela proposta de Burke, ${ }^{51}$ utilizamos as imagens como testemunhos históricos e estamos atentos que é necessário além da análise das imagens, estudar quem as elaborou, entre outras variáveis. Seria imprudente acreditar em um "olhar inocente" por parte do artista-viajante, isto é, que fosse totalmente objetivo, livre de expectativas e/ou preconceitos de qualquer tipo. A diversidade de nossos artistas-viajantes analisados reflete a multiplicidade de atividades realizadas em terras cariocas, como expedições científicas com preparo artístico e científico, ou diplomáticas, sem uma necessidade explícita desses traços. Desse modo, além de pertencerem a distintas nacionalidades, alguns foram marcados pelos estilos românticos e neoclássicos, e outros não tiveram nenhuma formação acadêmica. Os artistas de formação que acompanhavam as expedições científicas geralmente apresentavam as espécies vegetais com mais detalhes, como é possível verificar em Ender, que acompanhou a Missão Austríaca (1817 - 1821), e, em Rugendas, que participou da Expedição Langsdorff (1821 - 1829). Diferentemente destes, Chamberlain e Graham não tiveram formação artística acadêmica, considerados então como artistas amadores.

Observem na Figura 1 como ocorre a disposição dos ambientes rural, suburbano e urbano na paisagem carioca. Em primeiro plano, há a transição de um ambiente rural para o suburbano. O rural, à direita, está representado pela plantação de gramíneas, possivelmente de origem africana para servir como alimento para equídeos; ${ }^{52}$

\footnotetext{
${ }^{48}$ Warren Dean, A ferro e fogo: a história e a devastação da Mata Atlântica brasileira (São Paulo: Companhia das Letras, 1996) Diogo de Carvalho Cabral, Na presença da Floresta: Mata Atlâtica e História Colonial (Rio de Janeiro: Garamond/ FAPERJ, 2014). Gabriel Paes da Silva e Guedes-Bruni, Rejan R. "Um quebra-cabeça verde: "montando as peças" do reflorestamento empreendido na Floresta da Tijuca", Fronteiras: Journal of Social, Technological and Environmental Science, 7, 3 (2018): 58-77.

${ }^{49}$ Mary Karash, A vida dos escravos no Rio de Janeiro (1808-1850) (São Paulo, Companhia das Letras, 2000). Flávio dos Santos Gomes, A hidra e os pântanos: mocambos, quilombos e comunidades de fugitivos no Brasil (séculos XVII-XIX) (São Paulo: Ed UNESP / Ed Polis, 2005). Luís Carlos Soares, O “povo de Cam” na capital do Brasil: a escravidão urbana no Rio de Janeiro do século XIX (Rio de Janeiro: FAPERJ / 7Letras, 2007).

${ }^{50}$ Em cada imagem colocamos em nota de rodapé o link de acesso a sua versão colorida.

${ }^{51}$ Burke, Peter. Testemunha ocular: o uso de imagens como evidência histórica. 1 ed. (São Paulo: Editora Unesp: 2017) 318.

${ }^{52}$ Pelos traços de Ender não pudemos identificar com clareza qual gramínea foi retratada, podendo ser algum capim utilizado para forragem e alimentação de animais - talvez o capim-gordura (Melinis minutiflora P.Beauv.), o capim-colonião (Megathyrsus maximus (Jacq.) B.K.Simon \& S.W.L.Jacobs, podendo ser até mesmo outra gramínea exótica - ou cana-de-açúcar (Saccharum officinarum L.) para extração de açúcar. É importante observar que no século XIX quase não havia plantio de cana nos arrabaldes da cidade. Cf.
} 
e o suburbano, à esquerda, está representado pelas bananeiras e a contiguidade com os fundos de chácaras morro abaixo. A diversidade vegetal, resultante de um triplo encontro, é desenhada em diferentes formatos de folhas e de cores, com destaque para palmeiras. Assim, assumindo que folhas com formatos, cores e tamanhos diferentes são espécies distintas, é possível contabilizarmos cerca de seis espécies vegetais. Por conta da dificuldade na verificação das características diagnósticas, não foi possível especular as respectivas identificações em nível específico. Assim, alguns traços sendo mais definidos, permitem identificação, enquanto outros não. Essa definição gráfica é bastante característica dos pintores austríacos e alemães. Thomas Ender foi um pintor austríaco que estudou na Academia de Belas Artes de Viena e que se manteve na carreira ao longo da sua vida. O artista esteve no Brasil entre 1817 e 1818 como integrante da chamada Missão Austríaca, junto ao naturalista Carl F. Martius e o zoólogo Spix, com a função de registrar visualmente as paisagens brasileiras. ${ }^{53}$

Nessa aquarela, ao fundo, o morro de Santo Antônio denota o ambiente urbano com um conjunto de casas e o Aqueduto da Carioca (atual Arcos da Lapa). É interessante destacar que a topografia representada não existe mais desta forma. Da esquerda para direita, observamos uma parte do morro do Senado (desmontado em 1906), o morro de Santo Antônio (desmontado na segunda metade do século XX), onde se encontra os arcos do aqueduto, e atrás com umas edificações no cume, há o morro do Castelo (desmontado na década de 1920).

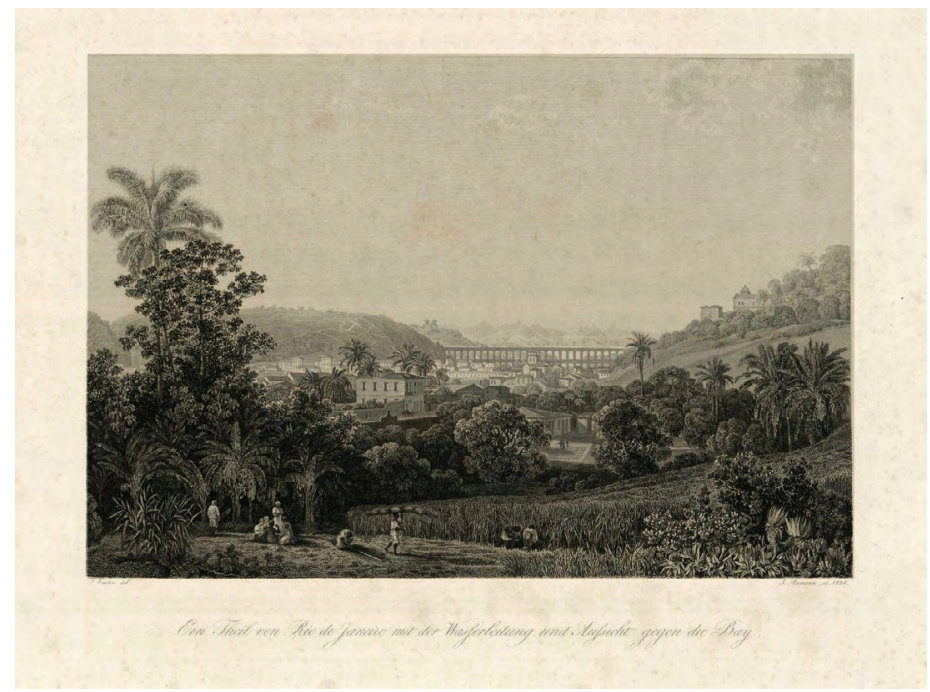

Figura 1. Thomas Ender, "Vista da Colina Mata Cavalos, em direção ao aqueduto do Rio de Janeiro", 1828, água forte. Fonte: Biblioteca Nacional do Brasil. ${ }^{54}$

\footnotetext{
Abreu, op. cit.. Dessa maneira, o mais provável é que se trate de uma espécie de gramínea que seria utilizada para alimentação animal, pois além do trabalho de negros/as escravizados/as, os cavalos, burros e outros equídeos possuíam fundamental importância para o trabalho rural e suburbano naquele contexto histórico.

${ }^{53}$ Bandeira e Wagner 58.

${ }^{54}$ Ansicht von der Anhöhe Matta Cavallos nach der Wasserleitung von Rio de Janeiro [Vista da Colina Mata
} 
Mesmo que nesta gravura, quando analisada em cores, seja predominante uma palheta amarelo ocre, quase como uma paisagem de cor outonal - o que não há no Rio de Janeiro -, a reconhecemos como uma paisagem tropical. A diversidade das plantas, as formas das montanhas, a presença de palmeiras, dos escravos negros/as ${ }^{55}$ e da arquitetura luso-brasileira, em conjunto, dão forma a esse panorama carioca. Entre o primeiro plano e o fundo, há uma faixa arborizada com embaúbas, palmeiras e outras espécies vegetais de cores, formatos e tamanhos distintos ao lado de grandes casas. Estas chácaras eram muito comuns nos subúrbios cariocas. Por trás dessa região da Colina Mata Cavalos, onde Ender estava localizado ao retratar a imagem, existiam as matas da Serra da Carioca. Essa proximidade das árvores, e o pequeno arvoredo por trás do Convento de Santa Teresa à direita, indica uma contiguidade com o ambiente florestal e o subúrbio carioca, que se beneficia da umidade, vento e escoamento das águas.

A atividade laboral na transformação da paisagem se faz presente pelos capinzais e outras espécies exóticas de interesse utilitário, e pela representação de trabalhadores/as negros/as na labuta da terra. Ao passo que dois cortam o capim, outro está carregando um fardo. Ao lado, um pequeno grupo está reunido para preparar o solo para um novo plantio ou estão apenas descansando. Por fim, no canto esquerdo, um indivíduo mira o bananal, talvez a planejar alguma atividade.

O Aqueduto da Carioca e as igrejas sobre o morro do Castelo, ao fundo, são detalhes que proporcionavam a identificação do local e evidenciam como o tecido urbano se mescla com a presença das plantas, de acordo com a percepção do autor. Esse aqueduto foi representado por diversos viajantes que estiveram no Brasil na primeira metade do século XIX. Localizado no atual bairro da Lapa, hoje ele é um dos cartõespostais mais importantes do Rio, sendo ainda bastante representativo da cidade.

$\mathrm{Na}$ imagem de Rugendas (Figura 2), a mureta do aqueduto no primeiro plano deixa evidente a presença do trabalho humano no ambiente florestal. Ao fundo, em relação ao plano principal, os arcos estão como referência do núcleo urbano da cidade.

Cavalos, em direção ao aqueduto do Rio de Janeiro]. En: Biblioteca Nacional do Brasil. Rio de Janeiro http://objdigital.bn.br/acervo_digital/div_iconografia/icon594979.jpg (18 de Feb. 2021).

${ }^{55}$ Para este artigo, consideramos que raça é um conceito social e histórico com diferentes significados no tempo e no espaço. Para o Rio de Janeiro oitocentista, as representações de negros e brancos serão diferenciadas pela cor de pele, vestimentas e atividade que desempenha nas gravuras. Não nos interessa discernir o branco europeu do branco brasileiro em nossas análises. 


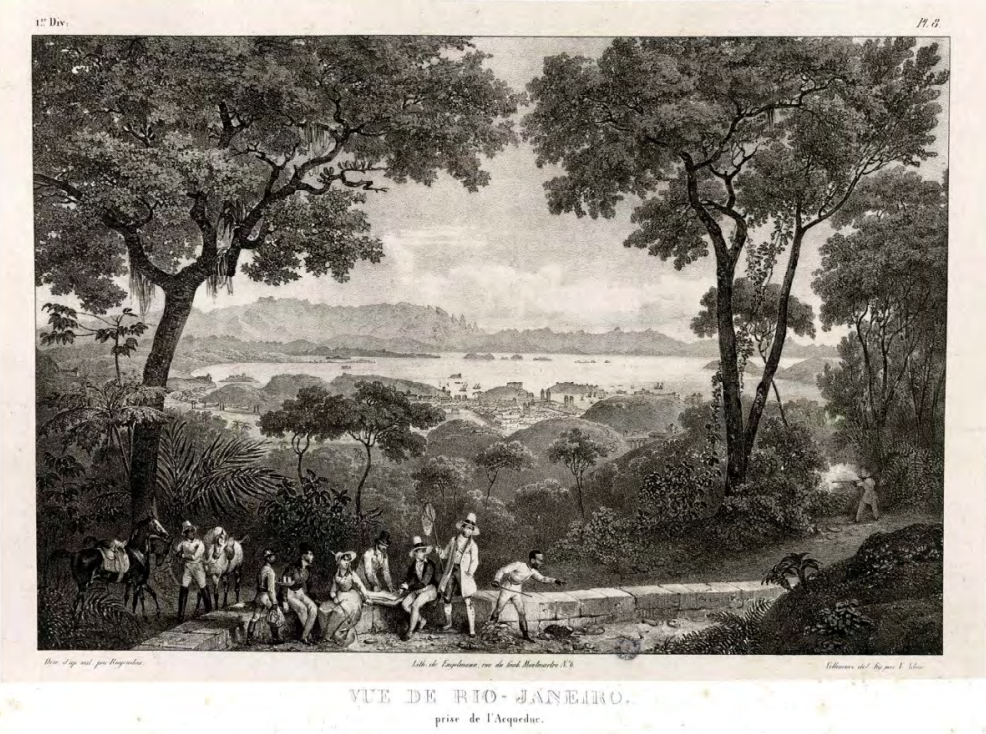

Figura 2. Johann Moritz Rugendas, "Vista do Rio de Janeiro retirada do Aqueduto", 1827-1835, litografia sobre papel. Fonte: Biblioteca Nacional do Brasil. ${ }^{56}$

Johann M. Rugendas foi um artista alemão com formação acadêmica em arte e membro de uma família tradicionalmente de artistas. Frequentou a Academia de Belas Artes de Munique e produziu um livro representativo sobre a imagem do território luso-brasileiro oitocentista. Voyage Pittoresque dans le Brésil (1835) foi publicado quando de seu retorno à Europa, sendo um condensado de sua viagem como pintor da Expedição Langsdorff (Expedição Russa) ${ }^{57}$. Nesta prancha que compõe o referente livro, Rugendas diz que "o espectador está colocado perto do grande Aqueduto da Carioca, numa das colinas que vão do Corcovado à praia. Atrás da cidade, a oeste, e sobre a primeira colina à direita, vê-se o Convento de Santa Tereza e, ao pé desse convento, alguns arcos do Aqueduto da Carioca" ${ }^{58} \mathrm{O}$ artista comenta que essa prancha "representa a cidade e a baía, vistas do lado da serra", ${ }^{59}$ fazendo uma detalhada descrição da vista. No entanto, o plano principal da gravura nos possibilita explorar mais suas intenções. ${ }^{60}$

\footnotetext{
${ }_{56}$ Vue de Rio de Janeiro prise de l'aqueduc. [Vista do Rio de Janeiro retirada do Aqueduto]. En: Biblioteca Nacional do Brasil. Rio de Janeiro. http://objdigital.bn.br/acervo_digital/div_iconografia/icon94994/ icon94994_035.jpglacqueduc (18 Feb. 2021).

${ }^{57}$ Andrea Roca, "Imagens construtoras da nação: Rugendas e seus desenhos sobre indígenas no Brasil e na Argentina", en Iluminuras, Porto Alegre, 18, 43(2017): 29-64.

${ }^{58}$ Rugendas 22.

${ }^{59}$ Rugendas 22.

${ }^{60}$ Dado que esta imagem faz parte do diário de viagem do próprio Rugendas, vamos considerar que qualquer sobreposição de cena sobre o desenho original por parte do gravador foi adotada pelo artista para publicação.
} 
Esta cena se trata, possivelmente, de uma prática que ele vivenciou inúmeras vezes, na qual verificamos o uso de um equipamento específico para a coleta de material da flora ou da fauna do Brasil. Sentados na mureta, dois homens brancos fazem anotações ou coletam material botânico (exsicatas ${ }^{61}$ ). Em pé, com o puçá, ferramenta de cabo comprido e uma rede circular na ponta, um deles parece caçar borboletas. Ao seu lado, há um homem negro apontando para uma cobra. Enquanto ao fundo, com uma espingarda, outro mira para algum animal que se oculta dentro da mata. Costume comum no Rio de Janeiro escravocrata é a figura de escravos naturalistas que acompanhavam os viajantes não só como guias e mateiros, mas como verdadeiros parataxonomistas, ${ }^{62}$ reconhecendo e coletando os espécimes. ${ }^{63}$ Além desse protagonismo nas ciências naturais, observamos no rapaz com a bandeja o clássico trabalho subalterno de tarefas servis aos brancos.

Esse cenário do primeiro plano oferece um pouco das "curiosidades" dessas terras tão distantes do então epicentro europeu. São elementos que dão um sabor especial à vista panorâmica da cidade e que, ao mesmo tempo, são representativos do contexto dela: a natureza local, a presença de escravos/as negros/as, a cultura europeia e neo-europeia nos hábitos e na arquitetura, assim como a presença de naturalistas originários de distintos países. Como um viajante, o artista teve o cuidado de representar a cidade não somente por sua natureza, mas também pelas práticas "civilizatórias" de seu tempo e que estavam presentes na capital do Império lusobrasileiro. Deste modo, esta imagem descreve uma cultura exclusiva, marcada pela diversidade natural/cultural, que revela uma das facetas do Brasil à Europa. Diener ${ }^{64}$ deixa clara a técnica de construção da paisagem de Rugendas, a qual, no seu ateliê, unia os registros desenhados durante a viagem para montar o aspecto geral de uma dada região. ${ }^{65} \mathrm{O}$ historiador comenta que Rugendas:

Enriquece a paisagem até recriar o espaço global da região, incorporando espécimes da vegetação próprios da zona climática e figurinhas decorativas típicas do lugar. (...) Os quadros de paisagem de Rugendas parecem, a princípio, uma vista casual, mas de fato representam um resumo ideal do que é possível encontrar numa determinada região. É precisamente neste ponto que se evidencia sua afinidade com o Naturgemälde, ou Quadro da Natureza, de Humboldt. ${ }^{66}$

\footnotetext{
${ }^{61}$ Exsicatas são coletas de espécimes vegetais que são prensadas e secas para maior conservação, e que podem ser utilizadas em estudos botânicos posteriores. No quadro, é plausível supor isso, a partir do movimento do homem em amarelo de prensar.

${ }^{62}$ Parataxonomistas são indivíduos com um saber naturalista empírico sem uma formação profissional acadêmica. Frequentemente acompanhavam naturalistas no passado e, hoje em dia, acompanham os biólogos, como mateiros. Por se tratarem, comumente, de antigos caçadores e/ou madeireiros e por possuírem um conhecimento acumulado, estas pessoas conhecem intimamente a dinâmica florestal, como, por exemplo: utilidades das espécies, qualidade das madeiras, rotina dos animais, entre outros.

${ }^{63}$ Moreira, Ildeu de Castro. "O escravo do naturalista: o papel do conhecimento nativo nas viagens científicas do século 19”, Ciência hoje, 31, 184 (2002): 40-48.

${ }^{64}$ Pablo Diener, A América de Rugendas: obras e documentos (São Paulo: Estação Liberdade; Kosmos, 1999).

${ }^{65}$ Uma mesma gravura poderia ser publicada diversas vezes em diários de distintos autores. Nesse processo era comum a supressão ou adição de elementos da flora, da fauna ou de personagens nativos, como indígenas.

${ }^{66}$ Diener 19.
} 
O ambiente florestal foi representado em sua borda, com a cidade ao fundo e as matas no entorno de quem observa. Essa fronteira, chamada de ecótono pelos biólogos atuais, é justamente um dos principais elementos que fascinavam os viajantes europeus, então acostumados a pintar paisagens com um grande céu aberto ao fundo. Por um lado, nesse encontro, o artista retratou espécies que indicam a presença imponente da floresta, como as duas árvores de grande porte emoldurando a cena, e toda a diversidade vale abaixo. Observa-se também a estratificação e ocupação da verticalidade do território com a variedade de tons verdes das árvores de diferentes tamanhos, assim como trepadeiras e epífitas. Por outro lado, a existência de clareiras e áreas abertas é uma ótima oportunidade para o desenvolvimento de espécies pioneiras e de rápido crescimento, isto é, que necessitam de uma condição de sol pleno para se estabelecer e se desenvolver, como é o caso da embaúba (Cecropia spp.), no canto esquerdo da imagem. Rugendas destacou que:

A riqueza da vegetação é imensa; e a umidade agradável, a frescura desse lugar, parecem dar-lhe um vigor novo e realçar a magnificência de suas cores, de maneira que o brilho das flores que se veem nos arbustos, nas árvores e nas plantas, só é ultrapassado pela multidão e magnificência das borboletas, dos colibris, e de outros pássaros de variegada plumagem que aí procuram abrigo contra o ardor sufocante do sol. ${ }^{67}$

Por conta das características diagnósticas identificáveis contabilizamos cerca de oito espécies vegetais na Figura 2. Dentre elas, junto a embaúba, reconhecemos um feto arborescente, popularmente conhecido como samambaiaçu. As espécies que atendem por esse nome se destacam pela beleza que possuem e pelos diferentes usos que podem ser feitos a partir de seu caule, principalmente. Dessa maneira, podem ser consideradas como uma marca das florestas cariocas, a partir do século XX.

A presença de epífitas corrobora a ideia de um ambiente florestal. Chamadas de "plantas atmosféricas", elas vivem apoiadas em cima de outras árvores e tem um papel fundamental na dinâmica ecológica, servindo como recursos alimentares e como microambientes para fauna de dossel. Muitas vezes são consideradas como bioindicadoras do estado atual das florestas, pois são sensíveis ${ }^{68}$ aos impactos antrópicos. Sobre epífitas e a ocupação do espaço vertical pelas plantas nas matas cariocas, Rugendas destacou que:

Para estabelecer uma comparação entre as florestas do Brasil e as mais belas e antigas do nosso continente, não basta ressaltar apenas a maior extensão das primeiras, ou o tamanho das árvores, faz-se imprescindível assinalar ainda, como diferenças características, as variedades infinitas das formas dos troncos e das folhas e galhos, além da riqueza das flores e da indizível abundância de plantas inferiores e trepadeiras que preenchem os intervalos existentes entre as árvores, contornam-nas e enlaçam-lhes os galhos, formando dessa maneira um verdadeiro caos vegetal. Nossas florestas não podem sequer dar-nos uma ideia mesmo longínqua. ${ }^{69}$

\footnotetext{
${ }^{67}$ Rugendas 24.

${ }^{68}$ Anísio Pereira, "Mata Atlântica: uma abordagem geográfica", Nucleus, 6, (2009): 27-52.

${ }^{69}$ Rugendas 14.
} 
Como destacado por Schwarcz: "o Brasil era, para esses viajantes, ao mesmo tempo um velho conhecido e um grande desconhecido. Era o país da flora exuberante e da enorme fauna; mas também quase um continente misterioso, caracterizado por gentes de hábitos estranhos" 70

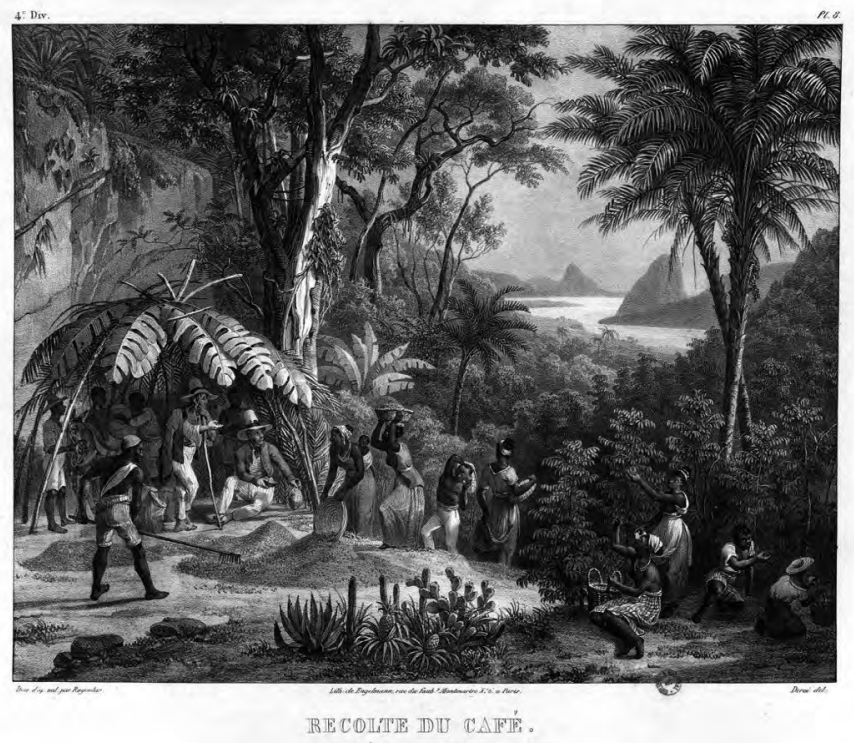

Figura 3. Johann Moritz Rugendas, "Recolte du café”, 1835, litografia sobre papel. Fonte: Biblioteca Nacional do Brasil. ${ }^{71}$

Na Figura 3, vemos o trabalho de colheita do café (possivelmente Coffea arabica L.) no que parece ser a Serra da Carioca. Publicada no seu diário de viagem, o artista utiliza vários ícones que expressam a brasilidade que ele intenciona divulgar em seu livro. A partir das gravuras que vimos até agora percebemos que a junção de negros/as escravizados/as e vegetação formavam um elemento de fácil identificação do Brasil oitocentista.

Rugendas destacou no primeiro plano as diversas etapas da produção de café, evidenciando a condição de escravidão na realização de tarefas, como: colheita dos frutos, secagem do café, transporte das sacas nas costas e carregamento em uma mula para o transporte do apreciado produto. Além destas evidências, a própria presença dos cafezais é uma coprodução da Rubiaceae e do trabalho negro. Suas mudas possuem um crescimento otimizado em áreas sombreadas. No entanto, devido às constantes fugas de escravos/as (aspecto comum ao cativeiro) e aos costumes

\footnotetext{
${ }^{70}$ Schwarcz 19-52; 13.

${ }^{71}$ Recolte du café [Colheita do café]. En: Biblioteca Nacional do Brasil. Rio de Janeiro. http://objdigital. bn.br/acervo_digital/div_iconografia/icon94994/icon94994_178.jpg (18 Feb. 2021).
} 
coloniais da monocultura, a floresta era derrubada a ferro e fogo antes de se iniciar o plantio de forma linear na direção a montante da encosta. À vista disso, grande parte dos cafezais que tiveram sucesso nessa modalidade agrícola contraditória se deu nas sombras dos vales. A particularidade do cafezeiro junto à realidade histórica do Rio de Janeiro oitocentista fez com que esta cultura se alastrasse pelos vales cariocas. $\mathrm{O}$ desmatamento para a cafeicultura somado aos cortes para lenha e madeira alterou a dinâmica da floresta e dos seus rios, comprometendo a oferta de água para a cidade ${ }^{72}$.

Próximo ao trabalho negro, destacado no centro do primeiro plano, há um aglomerado de espécies de sol pleno (abacaxis e cactáceas), que contrasta com a meia luz da mata e relaciona à necessidade de uma clareira para a secagem dos grãos de café. Nesse sentido, a bananeira foi utilizada para sombrear o carregamento das sacas de café no lombo da mula e os homens que observam.

Rugendas retrata uma profusão de formas de vida em relações ecológicas com a topografia local, com espécies herbáceas, arbustivas, arbóreas e palmeiras, assim como uma vegetação que cresce em cima de outras plantas (epífitas) e de rochas (rupícolas). A imensa rocha coberta de musgos e bromélias à esquerda compõe a moldura estética do quadro. Junto às grandes árvores também cobertas de pequenas plantas, este trecho é ícone do que chamamos, comumente, como Mata Atlântica. Este tipo de ambiente de matas é marcado por alta pluviosidade e umidade, por uma elevada densidade florestal, rica biodiversidade e por uma utilização vertical do espaço com trepadeiras, epífitas e árvores de diferentes portes, assim como das variações topográficas dos morros e os afloramentos rochosos. Essa diversidade de ambientes junto à competição por espaço, por luz e por nutrientes, resultou numa rica biodiversidade florestal ${ }^{73}$.

No caso das paisagens cariocas, as formações rochosas são bem presentes e representativas na iconografia, como é o caso icônico do Pão de Açúcar. Este morro foi se tornando, especialmente, a partir das publicações dos diários de viagem, um dos mais importantes identificadores das paisagens brasileiras e não somente da carioca - como ainda o é para um estrangeiro atual. Ao avistar essa formação rochosa nas gravuras, o leitor facilmente identificaria o Brasil. Nesse contexto, é importante, então, mencionar que o Brasil começa a ser reconhecido a partir desses símbolos naturais/ culturais que os viajantes divulgaram em seus países de origem. Sendo ampla essa divulgação, como já mencionamos, esses símbolos foram formando uma ideia de Brasil baseada em sua natureza exuberante, nas suas gentes de hábitos raros e, mais que nada, nessa convivência íntima entre universo natural e universo social. Nesse processo, a topografia e o conjunto de espécies da flora brasileira foram se transformando em uma identidade forte não só da cidade carioca, mas também da ideia de Brasil que era exportada. Além disso, como as espécies exóticas e a presença humana podem estar

\footnotetext{
${ }^{72}$ Drummond, José Augusto. "O jardim dentro da máquina: breve história ambiental da floresta da Tijuca”. Revista Estudos Históricos, 1, 2 (1998). Capilé, Bruno. Os muitos rios do Rio de Janeiro: transformações e interações entre dinâmicas sociais e sistemas fluviais na cidade do Rio de Janeiro (1850-1889) (Tesis doctoral, Universidade Federal do Rio de Janeiro, 2018).

${ }^{73}$ Anísio Pereira, "Mata Atlântica: uma abordagem geográfica", Nucleus, 6,1 (2009): 27-52.
} 
relacionadas, essa identidade levava consigo muito do trabalho humano oculto, ou não, na paisagem. Rugendas exemplificou tal relação de forma exemplar.

$\mathrm{Na}$ Figura 4 temos a representação do ambiente rural/suburbano. Chamberlain reproduz a antiga freguesia do Engenho Velho (chamada por ele de Aldeia do Andarahy), em que diz: "vários comerciantes brasileiros ricos possuem vivendas campestres". ${ }^{74}$ A representação das montanhas do maciço da Tijuca ao fundo possui traços que não ressaltam a diversidade florestal. Comparando com Ender ou com Rugendas, essa gravura aparenta menos apuro artístico. As formas são menos elaboradas artisticamente, sendo mais uma ilustração informativa do que estética.

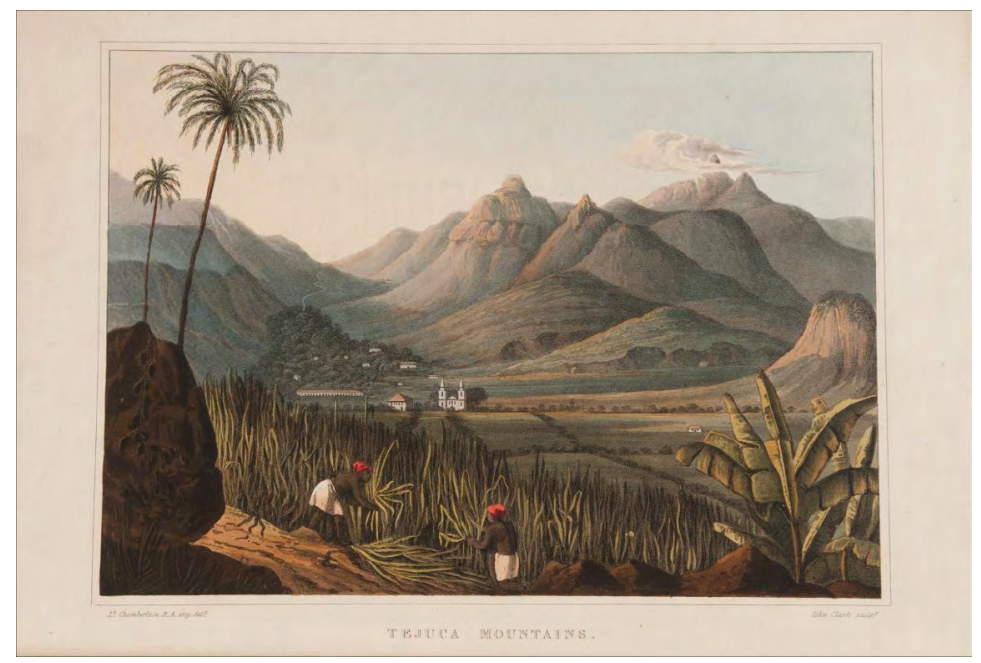

Figura 4. Henry Chamberlain, “Tejuca Mountains”, 1821, água-tinta e aquarela sobre papel. Fonte: Biblioteca Nacional do Brasil. ${ }^{75}$

De fato, Chamberlain não teve formação artística acadêmica. Ele veio para o Brasil como oficial da Artilharia Real Britânica, em 1819, ao acompanhar o seu pai que era cônsul-geral da Inglaterra. Permaneceu no Rio de Janeiro até 1820, dedicandose a desenhar e a pintar os aspectos da cidade. Em 1821, publicou em Londres o álbum Views and Costumes of the City and Neighbourhood of Rio de Janeiro, ilustrado com 36 gravuras em água-tinta, coloridas e acompanhadas por textos descritivos. ${ }^{76}$

\footnotetext{
${ }^{74}$ Chamberlain, Henry. Vistas e costumes da cidade e arredores do Rio de Janeiro em 1819-1820 (Rio de Janeiro: São Paulo: Livraria Kosmos Editora, [1821] 1945) 143.

${ }^{75}$ Tejuca Mountains [Montanhas da Tijuca]. Biblioteca Nacional do Brasil. Rio de Janeiro. http://objdigital. bn.br/acervo_digital/div_obrasraras/or8884i3.jpghttps://www.brasilianaiconografica.art.br/obras/19450/ tejuca-mountains (18 Feb. 2021).

${ }^{76}$ Brasiliana Iconografica. Henry Chamberlain. https://www.brasilianaiconografica.art.br/autor/18448/ henry-chamberlain (26 Oct. 2020).
} 
Como militar, Chamberlain provavelmente se preocupou mais em registrar os aspectos característicos da cidade e do cotidiano carioca do que criar quadros artísticos. Entretanto, como comenta Martins, ${ }^{77}$ os viajantes ingleses tinham a intenção de oferecer aos leitores dos seus diários dados informativos que fossem transmitidos nas imagens de maneira esteticamente agradáveis. Deste modo, essa gravura originária do desenho de Chamberlain apresenta padrões estéticos da época, ao criar planos distintos que culminam em um ponto ao fundo da composição, ao colocar uma cena ativa no primeiro plano e ao emoldurar a imagem com dois elementos maiores nos cantos do plano dianteiro (a rocha, a palmeira e a bananeira), entre outras coisas. Nesse sentido, Martins destacou:

\begin{abstract}
É assim que vai ser construída a ideia de uma paisagem “típica”, não exatamente bela ao olhar europeu, mas que permite ao viajante descrever as cenas de lugares distantes. No caso dos trópicos, a imagem que se forma "típica" é a de uma paisagem onde a natureza reina exuberante: uma paisagem-só-natureza onde as parcas referências a edificações servirão apenas para reiterar a ideia de uma paisagem não apenas de outros lugares, como também de outros tempos, por vezes acenando para uma época áurea, por outras, para um mundo primitivo. ${ }^{78}$
\end{abstract}

No texto que acompanha a gravura, Chamberlain diz que grande parte da região montanhosa era patrimônio do Visconde d'Asseca e que "vários lotes foram cultivados por emigrantes da Europa, franceses na maioria, que ali iniciaram consideráveis plantações de café, para o que o clima e o solo são particularmente apropriados". ${ }^{79}$ De fato, existem documentos que confirmam esse tipo de cultivo na primeira metade do XIX ${ }^{80}$ No vale do Engenho Velho vemos a igreja de São Francisco Xavier, ainda existente, como outras construções ao fundo, as quais podem ser uma fábrica de papel, uma tecelagem e uma estamparia de algodão, mencionadas pelo autor em seu texto. Ele provavelmente se referia a antiga Fábrica de Chitas (no atual bairro da Tijuca), que por volta dessa época estava em atividade. ${ }^{81}$

Ainda nesse plano, ao fundo, reparem a diferença de escala entre a igreja e as montanhas, indicando a marcante presença das últimas sobre as construções humanas. Curiosamente ele retrata nesse plano uma floresta mais densa, talvez para diferenciar as zonas cultivadas das montanhas com as zonas de mata conservada. Igualmente, podemos ver um rio que corre em meio à mata e que desce colina abaixo: provavelmente o Trapicheiros. O artista-viajante pode também ter relacionado a formação densa da mata com a presença da água. Mesmo sendo o título da obra representativo da cadeia de montanhas ao fundo, Chamberlain figura no primeiro plano da imagem a

\footnotetext{
${ }^{77}$ Luciana Martins, O Rio de Janeiro dos viajantes: o olhar britânico (1800-1850) (Rio de Janeiro: Jorge Zahar Ed., 2001) 42.

${ }^{78}$ Martins 60.

${ }^{79}$ Henry Chamberlain, Vistas e costumes da cidade e arredores do Rio de Janeiro em 1819-1820 (Rio de Janeiro: São Paulo: Livraria Kosmos Editora, [1821] 1945) 143.

${ }^{80}$ Abreu.

${ }^{81}$ Isabel Drumond Braga, "Teares, Fios e Tecidos em Viagem: Produções e Exportações da Real Fábrica das Sedas para o Brasil (1734-1821)”, Revista de Artes Decorativas, 4 (2010).
} 
colheita de alguma gramínea por dois personagens negros, provavelmente escravos. Ele comenta que esse seria um capim originário da Angola, usado por equinos e bovinos. Da maneira que está disposto na imagem, parece ser uma plantação para atender à alimentação dos animais mencionados. Chamberlain pode estar se referindo ao capim-gordura, ao capim-colonião ou a alguma outra gramínea de origem africana, bastante disseminados pela região sudeste do Brasil após a sua colonização pelos portugueses. Atualmente, é comum ver vastas áreas de vales entre Rio de Janeiro e São Paulo dominadas por gramíneas exóticas, geralmente associadas à presença e criação de gado, posterior ao cultivo do café. ${ }^{82}$ Fazendo uma leitura da imagem, é possível associar as montanhas ao capim plantado no vale, devido ao tema do transporte e da geração de energia necessária para os cultivos por meio de quadrúpedes. Como outra fonte de energia, a presença da força braçal negra foi fundamental para a manutenção dessas terras produtivas, sem eles a "maquinaria" não poderia funcionar.

$\mathrm{Na}$ Figura 5, observamos outro quadro feito por uma artista britânica e contemporânea de Chamberlain: Maria Graham. Nesta imagem, como na anterior (Figura 4), o observador está numa área do subúrbio, tendo as montanhas ao fundo. Sobre a paisagem suburbana, Graham menciona em seu diário que as “sebes de acácias e mimosas cercam os jardins, cheios de bananeiras, laranjeiras e outras frutas, que cercam cada vila". ${ }^{83}$ Neste sentido, a escrita auxiliou em nossa compreensão desta paisagem.

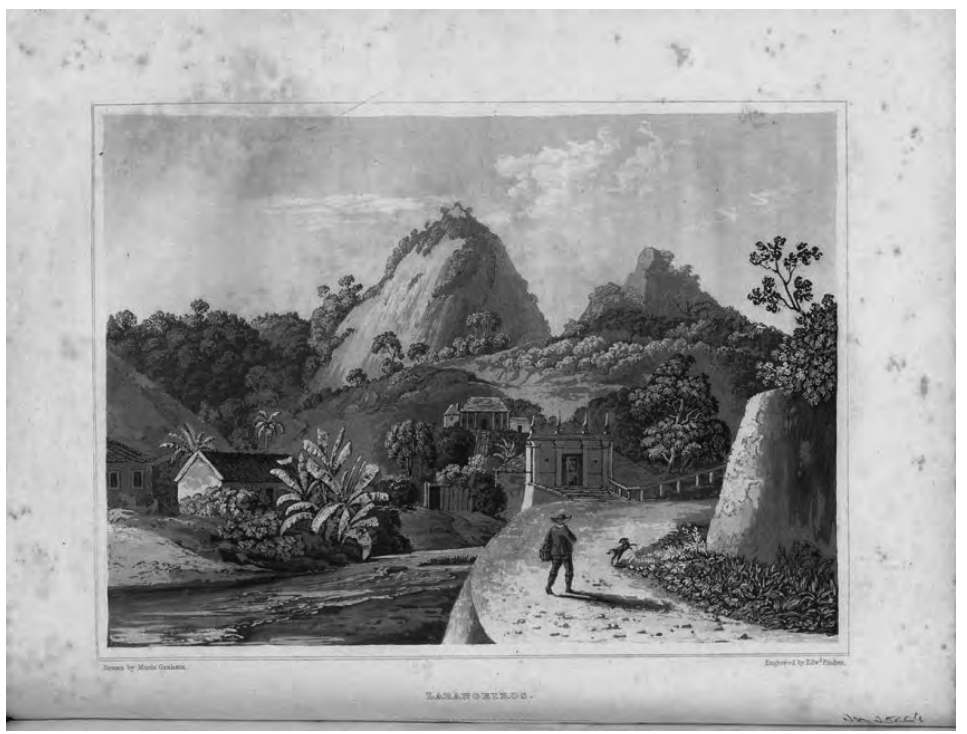

Figura 5. Maria Graham, “Laranjeiras”, 1821, desenho. Fonte: Biblioteca Nacional do Brasil. ${ }^{84}$

\footnotetext{
${ }^{82}$ Rogério Ribeiro de e Lazos Oliveira, Adi (eds.), Geografia Histórica do Café no Vale do Rio Paraíba do Sul (Rio de Janeiro: Ed. PUC-Rio, 2018).

${ }^{83}$ Graham, Maria. Diário de uma viagem ao Brasil e de uma estada nesse país: durante parte dos anos de 1821, 1822 e 1823 (São Paulo, Brasiliana, 8, [1824] 1956) 162.

${ }^{84}$ Graham, 162.
} 
Mais uma vez, o encontro entre o ambiente florestal e o suburbano foi representado através das espécies mais carismáticas: embaúbas e palmeiras nas matas, e bananeiras nos arrabaldes. O rio Carioca, com o nível baixo e ligeiramente assoreado, possui um destaque harmonioso na estética do quadro. Ele aparece em primeiro plano e sinuosamente some junto à estrada. Descendo das matas da Serra da Carioca, este rio é icônico na cultura histórica do Rio de Janeiro. Primeiro rio que efetivamente abasteceu a cidade, tem seu sistema de canalização pelo aqueduto iniciado no século XVIII. As águas que descem nesta paisagem não foram desviadas para a cidade pelo sistema hídrico. O desmatamento das primeiras décadas do século XIX, para a cultura do café e para oferecer lenha e carvão vegetal para a cidade, agravou a diminuição de seu fluxo e o aporte de sedimentos que resultaram em seu assoreamento. ${ }^{85}$ Sobre o uso dessas águas, Graham escreve que mais acima um grupo de lavadeiras aproveitaram um trecho de pedras para realizar seu trabalho. Sem desenhá-las, a autora comenta que eram negras em sua maioria e usavam um lenço vermelho ou branco em volta da cabeça, uma manta dobrada sobre o ombro e uma grande saia. ${ }^{86}$

Nessa prancha, Graham cria um caminho que guia o nosso olhar para a altivez da pedra do Corcovado. A partir da luz que se centraliza no caminho, no qual estão uma figura humana e um cachorro, o nosso olhar segue em uma leve diagonal que percorre a entrada e a casa principal de uma chácara, o direcionando para a majestosa formação rochosa e florestal. Com essa técnica ela localiza a rocha na centralidade da imagem, dando uma efetiva importância a esse "personagem" típico da cidade carioca, dizendo que esse "cume pitoresco encerra o cenário". ${ }^{87} \mathrm{O}$ que foi ressaltado pela artista-viajante há cerca de duzentos anos se perpetuou na atualidade. Desde 1931 o morro do Corcovado abriga a estátua do Cristo Redentor, permanecendo hoje em dia como um dos ícones mais importantes não somente do Rio de Janeiro, mas igualmente do Brasil.

De fato, a estética do pitoresco se faz realmente visível na imagem. A variedade de elementos que formam o conjunto da obra faz o nosso olhar transitar pelos distintos objetos que a conformam harmoniosamente: o rio que corre na direção do espectador, as bananeiras que coroam a casa localizada à margem direita do rio, o conjunto florestal que desce em direção às mesmas, as quais recebem uma luz especial que as destaca, além da equilibrada distribuição dos conjuntos arbóreos sobre a imponente formação rochosa. Nessa imagem foi particularmente difícil identificar outras espécies, além de bananeiras, palmeiras e embaúbas, pelo fato de a pintora retratar conjuntos vegetacionais, ao invés de tratar em detalhes as espécies. Todo esse movimento que a autora provoca em nosso olhar, até que seja alcançado o cume, dispensa qualquer rigidez de traços para que as linhas sinuosas imperem na composição. Tal dinâmica apresentada é típica desse estilo, o qual entre a variedade

\footnotetext{
${ }^{85}$ Bruno Capilé, "Direitos ou privilégios? Os embates nos usos dos rios nas serras do Rio de Janeiro no Segundo Reinado", en Sonkajarvi, Hanna; Vital, André Vasquez. (eds). A água no Brasil: conflitos//atores// práticas (São Paulo: Alameda, 2019) 145-185.

${ }^{86}$ Graham 161.

${ }^{87}$ Greham 162.
} 
de objetos, luz e linhas é criada uma harmonia agradável aos olhos, e por que não, também aos sentimentos do espectador/leitor.

Diferente dos outros artistas-viajantes, Graham tinha uma relação mais próxima das plantas do que do próprio desenho. Como Chamberlain, ela não teve uma formação artística acadêmica. No entanto, a riqueza de detalhes e o olhar estético de Graham são característicos tanto de sua escrita quanto de sua produção iconográfica. Em visita ao Jardim Botânico do Rio de Janeiro, em 1821, ficou muito contente com a coleção botânica, embora tenha ficado desapontada por não encontrar nenhuma coleção de plantas nativas nessa ocasião. Em sua volta no ano seguinte, contentouse com o cambucá (Plinia edulis (Vell.) Sobral), a jabuticaba (Plinia cauliflora (Mart.) Kausel) e a grumixama (Eugenia brasiliensis Lam.), comparando com plantas conhecidas pelos europeus e seus usos mais familiares como licores. ${ }^{88}$

Ótima taxonomista vegetal, em meio a mais de duzentos colaboradores, foi uma das duas únicas mulheres a participarem da grandiosa obra botânica Flora Brasiliensis, organizada originalmente por Carl von Martius. Em mais uma das muitas viagens intercontinentais, veio ao Rio de Janeiro junto a seu marido, o oficial da marinha inglesa Thomas Graham. Dentre as suas moradias intermitentes, morou no vale do rio Carioca, onde explorou a "floresta virgem" atrás de sua casa, onde esboçou desenhos de paisagens e plantas, e coletou espécimes botânicos que eram enviados ao dr. William Jackson Hooker, diretor do Jardim Botânico de Kew. Seus desenhos ilustram o seu livro Journal of a Voyage to Brazil and Residence there during part of years $1821,1822,1823$, publicado pela primeira vez em Londres em $1824{ }^{89}$

\section{Considerações finais}

A metodologia proposta destaca elementos presentes nas iconografias enquanto transformadores das paisagens, como as plantas e o trabalho escravo. A representação das plantas pelos artistas-viajantes respondiam à função de registro da espécie e ao sentido estético na composição. Pelo carisma vegetal, algumas espécies se destacaram pelo seu aspecto visual, pela interação com o seu entorno ou até mesmo foram inseridas nas imagens com um sentido decorativo. Coletivamente, vemos que os cafezeiros e capinzais foram plantados nas zonas rurais produtoras de artigos de exportação; enquanto bananeiras e outras frutíferas estiveram presente nas quintas e chácaras dos subúrbios cariocas. Tais espécies eram, em geral, representadas juntamente à figura dos escravos/as, de maneira que eram relacionadas ao cultivo, ao trabalho braçal e aos costumes que estavam sendo formados.

Igualmente, percebemos essa relação entre cultivo e o trabalho escravo como a atuação de agentes no processo de transformação da paisagem carioca. Ou seja, pelo ponto de vista da história ambiental podemos perceber a flora e escravos/as como agentes de transformação, sem reduzi-los a serem meros elementos adicionais

\footnotetext{
${ }^{88}$ Greham 334.

${ }^{89}$ Ariane Luna Peixoto y Tarciso de Sousa Filgueiras, "Maria Graham: anotações sobre a flora do Brasil”, Acta bot. Bras, 22, 4 (2008): 992-998.
} 
representados nas gravuras analisadas. Deste modo, nossa intenção foi mostrar que eles/as estão presentes na alteração de florestas, em cultivos ou no processo de formação dos atuais bairros da cidade (Engenho Novo, Tijuca, Centro). A partir de uma leitura interdisciplinar, eles/as deixam de ser elementos passivos e se tornam ativos na história da paisagem carioca. Da mesma maneira, as variadas espécies vegetais, nativas ou exóticas, foram vistas por nós como agentes de igual força transformadora que os agentes humanos. Ao ser reconhecida a diversidade vegetal que compunha a "natureza" carioca representada pelos artistas-viajantes, constatamos por meio das gravuras que essa natureza já estaria bastante alterada nos inícios do século XIX. Como já comentado no início do artigo, levamos em conta à imaginação artística dos viajantes e dos gravadores ao momento de elaboração das paisagens pictóricas, entretanto muitas das informações visuais aí presentes são confirmadas ao serem entrecruzadas com outras fontes relativas à composição vegetativa aproximada da época. Ou seja, através da abordagem interdisciplinar fica evidente que estas imagens são valiosas fontes para a história ambiental, justamente por seu conteúdo histórico, socioambiental e cultural.

A rica diversidade presente nas florestas foram expressas de diferentes maneiras pelos artistas-viajantes. Como cenários pitorescos, como uma formação típica da região e por sua diversidade vegetal. Ao mesmo tempo, individualmente, algumas espécies arbóreas foram frequentemente destacadas nas pinturas, especialmente as embaúbas nas áreas de clareiras dos mirantes. Portanto, é interessante notar que a identidade brasileira foi sendo criada, acima de tudo, por sua diversidade, a qual incluía fatores nativos e exóticos da flora, da fauna, das pessoas e de suas culturas, assim como incluía o próprio olhar estrangeiro. Um universo diversificado que em sua unidade representava toda uma vastidão de terras a serem conhecidas e exploradas. Nesse processo dinâmico, o Rio de Janeiro se tornou o cartão-postal de entrada para esse "novo" mundo chamado Brasil.

\section{Agradecimentos}

Os autores agradecem a Alexander Reis e ao Dr. Daniel Dutra Coelho Braga pela leitura crítica da primeira versão do artigo e pelas sugestões que contribuíram para enriquecer a versão final. Agradecemos também à Enciclopédia Itaú Cultural, à Brasiliana Iconográfica, e, especialmente, à Fundação Biblioteca Nacional pela cessão de uso das imagens. O presente trabalho foi realizado com apoio da Coordenação de Aperfeiçoamento de Pessoal de Nível Superior - Brasil (CAPES) Código de Financiamento 001, concedido ao segundo autor, e do Consejo Nacional de Investigaciones Científicas y Técnicas (CONICET), Argentina, concedido a terceira autora. 


\section{Bibliografia}

\section{Fuentes primarias}

\section{Libros}

Chamberlain, Henry. Vistas e costumes da cidade e arredores do Rio de Janeiro em 1819-1820. Rio de Janeiro: São Paulo: Livraria Kosmos Editora, [1821] 1945.

Graham, Maria. Diário de uma viagem ao Brasil e de uma estada nesse país: durante parte dos anos de 1821, 1822 e 1823. São Paulo, Brasiliana, v. 8, [1824] 1956.

Humboldt, Alexander von. Quadros da Natureza. São Paulo, Editora Brasileira: [1849] 1957.

Rugendas, Johann. M. Viagem Pitoresca através do Brasil. São Paulo: Círculo do Livro S. A., sin fecha.

\section{Fuentes secundarias}

\section{Libros}

Abreu, Maurício de. Natureza e Sociedade do Rio de Janeiro. Rio de Janeiro: SMCTE/ DGDIC/Divisão, 1992.

Argan, Giulio Carlo. Arte Moderna. São Paulo: Companhia das Letras, 2002.

Bandeira, Júlio e Wagner, Robert. Viagem nas Aquarelas de Thomas Ender - 18171818. 3 vol., Petrópolis: ed. Kapa, 2000.

Besse, Marc. Besse, Jean-Marc. Ver a terra: seis ensaios sobre a paisagem e a geografia. São Paulo, Ed. Perspectiva, 2006.

Brady, Emily. Aesthetics of the natural environment. Edinburgh University Press, 2003.

Burke, Peter. Testemunha ocular: o uso de imagens como evidência histórica. 1 ed. São Paulo: Editora Unesp: 2017.

Cabral, Diogo de Carvalho. Na presença da Floresta: Mata Atlântica e História Colonial. Rio de Janeiro: Garamond/ FAPERJ, 2014.

Dantes, Maria Amélia M. (ed). Espaços da Ciência no Brasil: 1800-1930. Rio de Janeiro: Editora Fiocruz, 2001. 
Dean, Warren. A ferro e fogo: a história e a devastação da Mata Atlântica brasileira. São Paulo: Companhia das Letras, 1996.

Diener, Pablo. A América de Rugendas: obras e documentos. São Paulo: Estação Liberdade; Kosmos, 1999.

Gombrich, E. H. História da arte. Rio de Janeiro, LTD, 1999.

Gomes, Flávio dos Santos. A hidra e os pântanos: mocambos, quilombos e comunidades de fugitivos no Brasil (séculos XVII-XIX). São Paulo: Ed UNESP / Ed Polis, 2005.

Karash, Mary. A vida dos escravos no Rio de Janeiro (1808-1850). São Paulo, Companhia das Letras, 2000.

Martins, Luciana. O Rio de Janeiro dos viajantes: o olhar britânico (1800-1850). Rio de Janeiro: Jorge Zahar Ed., 2001.

Naxara, Marcia Regina Capelari. Cientificismo e sensibilidade romântica. Brasília: Editora UNB, 2004.

Oliveira, Rogério e Lazos, Adi (ed.). Geografia Histórica do Café no Vale do Rio Paraíba do Sul. Rio de Janeiro: Ed. PUC-Rio, 2018.

Plumwood, Val. Environmental Culture: The Ecological Crisis of Reason. London: Routledge, 2002.

Soares, Luís Carlos. O "povo de Cam" na capital do Brasil: a escravidão urbana no Rio de Janeiro do século XIX. Rio de Janeiro: FAPERJ / 7Letras, 2007.

Soper, Kate. What is Nature? Oxford: Cambridge: Blackwell Publishers, 1995.

Stepan, Nancy. Picturing tropical nature. London: Reaktion Books Ltd, 2001.

White, Richard. The Organic Machine: the remaking of the Columbia River. New York: Hill and Wang, 1995.

Wolf, Norbert. Romanticism. London: Taschen, 2007.

\section{Capítulo de libro}

Alimonda, Hector. "La colonialidad de la naturaleza: una aproximación a la ecología política latinoamericana", en Alimonda, Hector (ed). La naturaleza colonizada: ecología política y minería en América Latina. Buenos Aires: CLACSO, 2011. 
La agencia compartida de plantas y humanos en la elaboración del mosaico paisajístico...

Capilé, Bruno. "Direitos ou privilégios? Os embates nos usos dos rios nas serras do Rio de Janeiro no Segundo Reinado”, en: Sonkajarvi, Hanna; Vital, André Vasquez. (eds). A água no Brasil: conflitos//atores//práticas. São Paulo: Alameda, 2019.

Cronon, William. "Un lugar para relatos: naturaleza, historia y narrativa", en: Palacio, Germán y Ulloa, Astrid (eds.) Repensando la naturaleza. Encuentros $y$ desencuentros disciplinarios en torno a lo ambiental. Bogotá: Universidad Nacional de Colombia/ICANH 2002.

Diener, Pablo. "Os artistas da expedição de G. H. Langsdorff”, en: Costa, Maria de Fátima; et al. O Brasil de hoje no espelho do século XIX: artistas alemães e brasileiros refazem a expedição Langsdorff. São Paulo: Estação Liberdade, 1995.

Moraes, Rubens Borba. "Prefácio", en: Chamberlain, Henry. Vistas e costumes da cidade e arredores do Rio de Janeiro em 1819-1820. Rio de Janeiro: São Paulo: Livraria Kosmos Editora, 1945.

Siqueira, Vera Beatriz. "Narrativas de Brasil: a Paisagem como Discurso". Oitocentos - Tomo III, en: Valle, Arthus; Dazzi, Camila; Portella, Isabel (eds). Intercambios culturais entre Brasil e Portugal. 2 edicao/(organizadores) - Rio de Janeiro: CEFET/RJ, 2014.

Siqueira, Vera Beatriz. "Contrastes naturais: imagens da flora brasileira", en: Ana Cecília Martins. (eds). Flora Brasileira: História, Arte \& Ciência. 1ed. Rio de Janeiro: Casa da Palavra, 2009.

Williams, Raymond. Ideias de natureza, en: Williams, Raymond. Cultura e materialismo. São Paulo: UNESP, 2011.

\section{Artículo en revistas}

Braga, Isabel Drumond. "Teares, Fios e Tecidos em Viagem: Produções e Exportações da Real Fábrica das Sedas para o Brasil (1734-1821)”, Revista de Artes Decorativas 4, (2010).

Corrêa, Dora Shellard. "História ambiental e paisagem", en HALAC - Revista de História Ambiental Latinoamericana y Caribeña. Belo Horizonte, 2, 1 (2013).

Corrêa, Dora Shellard. "Paisagens através de outros olhares", Revista de História Regional, 20, 2 (2015).

Drummond, José Augusto. “O jardim dentro da máquina: breve história ambiental da floresta da Tijuca", Revista Estudos Históricos, 1, 2 (1998).

França, Ana Marcela. "As "pitorescas" florestas da Mata Atlântica nas paisagens dos viajantes", en Revista Labirinto: Editora da Universidade Federal de Rondonia, año XVIII, 29 (2018). 
França, Ana Marcela. "As imagens de paisagem como testemunhos de transformação e memória de áreas de conservação”, Boletín De Estudios Geográficos, 112 (2019).

Gibson, Diana; Ellis, William. "Human and plant interfaces: relationality, knowledge and practices", Anthropology Southern Africa, 41 (2018).

Head, Leslie; Atchison, Jennifer. "Cultural ecology: Emerging human-plant geographies", en Progress in Human Geography, 33, 2 (2009).

Hitchings, Russell; Jones, Verity. "Living with plants and the exploration of botanical encounter in human geography research", Ethics Place Environment, 7 (2004).

Kury, Lorelai. "Viajantes-naturalistas no Brasil oitocentista: experiência, relato e imagem”, en História, Ciências, Saúde - Manguinhos, VIII (suplemento) (2001).

Langdon, Robert. "The banana as a key to early American and Polynesian history", The Journal of Pacific History, 28, 1 (1993).

Mattos, Cláudia Valadão. "A pintura de paisagem entre arte e ciência: Goethe, Hackert e Humboldt", Revista Terceira margem, VIII, 10 (2004).

Moreira, Ildeu de Castro. "O escravo do naturalista: o papel do conhecimento nativo nas viagens científicas do século 19”, Ciência hoje, 31, 184 (2002).

Oliveira, Rogério Ribeiro de. "Mata Atlântica, paleoterritórios e história ambiental", Ambiente \& Sociedade, 10, 2 (2007).

Oliveira, Rogério Ribeiro de; Engemann, Carlos. "História da paisagem e paisagens sem história: a presença humana na floresta atlântica do sudeste brasileiro", Revista Esboços, 18, 25 (2011).

Peixoto, Ariane Luna; Filgueiras, Tarciso de Sousa. "Maria Graham: anotações sobre a flora do Brasil", Acta bot. bras., 22, 4 (2008).

Pereira, Anísio. "Mata Atlântica: uma abordagem geográfica", Nucleus, 6, 1 (2009): $27-52$.

Pratt, Mary Louise. "Humboldt e a reinvenção da América", en Estudos Históricos, Rio de Janeiro, 4, 8 (1991).

Roca, Andrea. "Imagens construtoras da nação: Rugendas e seus desenhos sobre indígenas no Brasil e na Argentina", Iluminuras, Porto Alegre, 18, 43 (2017).

Ricotta, Lúcia. "A paisagem em Alexander von Humboldt: o modo descritivo dos quadros da natureza", Revista Usp, 46 (2000). 
La agencia compartida de plantas y humanos en la elaboración del mosaico paisajístico...

Ryan, John Charles. "Passive Flora? Reconsidering Nature's Agency through HumanPlant Studies (HPS)”, Societies, 2 (2012).

Sales, Gabriel Paes da Silva e Guedes-Bruni, Rejan R. "Um quebra-cabeça verde: "montando as peças" do reflorestamento empreendido na Floresta da Tijuca", Fronteiras: Journal of Social, Technological and Environmental Science, 7, 3 (2018): 58-77.

Schwarcz, Lilia Moritz. "Paisagem e Identidade: a construção de um modelo de nacionalidade herdado do período joanino", Acervo, 22, 1 (2009).

Steinberg, Ted. "Down to Earth: Nature, Agency, and Power in History", The American Historical Review, 107, 3 (2002).

Worster, Donald. "Para fazer história ambiental”, Revista Estudos Históricos, 4, 8 (1991).

\section{Tesis}

Capilé, Bruno. Os muitos rios do Rio de Janeiro: transformações e interações entre dinâmicas sociais e sistemas fluviais na cidade do Rio de Janeiro (1850-1889). (Tesis doctoral), Universidade Federal do Rio de Janeiro, 2018.

\section{Publicaciones en internet}

Jardim Botânico do Rio de Janeiro. Programa REFLORA, http://floradobrasil.jbrj. gov.br

Brasiliana Iconográfica. https://www.brasilianaiconografica.art.br

Enciclopédia Itaucultural. http://enciclopedia.itaucultural.org.br

Biblioteca Nacional do Brasil. http://bndigital.bn.gov.br/ 